\title{
THE MODERN PHILANTHROPIC FOUNDATION: A CRITIQUE AND A PROPOSAL
}

WiTH the blossoming of the modern philanthropic foundation, the age of bigness invaded the field of public charity. The foundation represents a new technique available to individuals who wish to devote their surplus wealth to public purposes. Unlike such traditional charitable institutions as hospitals, churches and schools, which conduct activities directly beneficial to the public, ${ }^{1}$ philanthropic foundations confine most of their activities to grants-in-aid to other charitable institutions or endeavors. ${ }^{2}$

Foundations are generally endowed with securities or land; ${ }^{3}$ and since foundation disbursements are typically made out of income earned by this wealth, ${ }^{4}$ endowments must be sizable if disbursements are to be effective. ${ }^{5}$ Moreover, the majority of foundations receive their total endowments from a single person, family, or business group. ${ }^{6}$ They are typically the product of large, private fortunes amassed in the United States during the past century. While there were less than 10 foundations in the United States in $1900,{ }^{8}$ this number rose to approximately 35 in 1915, 100 in

1. For a detailed history of traditional charitable endowments see Tusks, Tro Modern Pamanteropic Foundation and Private Property 3-28 (unpublished thesis submitted in 1947 in partial fulfilment of the requirements for the graduate degree in lav at Yale Law School, and soon to be published by the Yale University Press). This work: was the most helpful of all source material used in the preparation of this comment and will hereafter be cited as Tuxks. For shorter historical sketches see HAnnison And ANDREws, AMTERICAN Foundations for SOCIAL WeLfaRe 11-18 (1946) (eited hereafter as HaRRISON AND ANDREWS); Hollis, Evolution of the Philanthropic Foundation, 20 Educational Record 575 (1939); Orton, Endowments and Fonndalions in 5 Enicyc. Soc. Scr. 531-3 (1931) ; Rosenwald, Philanthropy in 17 Encyc. Brrrasurien 709 (1938); Note, The Use of Charituble Foundations for Avoidanee of Taxes, 34 VA. L. REv. 182, 183 (1948).

2. HarRison and Andrews 39; Tunks 34-5.

3. TUNRs c. III. The average assets of 76 foundations as of 1940 consisted approximately 50 per cent of secured loans, 35 per cent of common stocks, 5 per cent of preferred stocks and 10 per cent of real estate and other assets. Id. at 97. See also HARRISON AND ANDREwS 57.

4. See notes 66 and 67 infra.

5. The return on foundation investments is currently very low. HArsison Asid ANDREws 70. In 1946, a conservative estimate of foundation return on capital was placed at 3 per cent. Id. at 57. The yield on all investments of the Carnegie Corporation for 1942 and 1943 was 2.7 per cent. Tunks 99.

6. Orton, supra note 1 , at 533 ; TuNrs 35-6.

7. See Harrison AND ANDREws 19; Tunks 37, 56-62; Orton, supra note 1, at 533; Gow, Fonndations: Their Policies and Practices, Pittsburgh Record, July, 1933, p. 14 at 15-16; Note, The Use of Charitable Foundations for the Avoidance of Taxes, 34 VA. L. REv. 182, 183 (1948).

8. HARRISON AND ANDREwS 17-18; Tunks 40; Orton, rspro note 1, at 533; Fortune, Aug., 1947, p. 108 at 109 , col. 1.

9. Tunss 38,40 . 
$1930,{ }^{10} 162$ in $1940,{ }^{11}$ and 505 in $1944 .{ }^{12}$ The 1944 estimate, made by the Russell Sage Foundation, was restricted to foundations with assets in excess of $\$ 50,000 ;{ }^{13}$ and the total value of assets held by the 505 foundations was estimated at $\$ 1,817,817,299$.14 Of these assets, which represent the bulk of all foundation assets in the country, approximately 87 per cent were held by the 30 largest foundations. ${ }^{15}$

Bigness has been accompanied by breadth of purpose. Foundations typically refrain from direct relief of the needy; instead, they sponsor programs of study, experiment, correction, cure and prevention. ${ }^{10}$ In this

10. Twentiete Century Fund, American Foundations and tueir Fuelds 10 (1931) ; TuNKs 38, 41.

11. Sexbord, American Foundations and their Fields V 14 (1942).

12. Harrison AND ANDrEws 7, 103-185.

13. Id. at 214.

Different criteria for inclusion of organizations as foundations bring about different estimates. Thus, the Twentieth Century Fund estimate of 1948, including known foundations with assets of less than $\$ 50,000$, came to 899 . Ricl and DenRdornF, American Foundations and Their Fields VI 11 (1948) (cited hereafter as Ricu ANd DeARDORFF). And Tunks' estimate, as of 1944, based on more stringent criteria than those of the Russell Sage Foundation and the Twentieth Century Fund, included only 252 foundations. Tunks 46, 49. Tunks restricted his estimate to foundations making at least some grants to outside beneficiaries other than local relief organizations, and whose endowments were contributed by a small number of persons. See notes 2 and 6 sitpra and note 16 infra; Tunks 33-6. Furthermore, Tunks excluded foundations on which he could not acquire detailed data for purposes of classification, $i d$. at 47 , while the Russell Sage and Twentieth Century 'estimates included foundations about which relatively no information 'could be gathered. Harrison and ANDrews 104-185; RIcir AND DEARDORF, 244-65.

In contrast to Tunks' selective estimate, an unofficial, 1947 guess by the Trensury Department, including known and unknown foundations, came to more than 10,000 . Fortune, Aug., 1947, p. 108 at 109, col. 1.

14. HaRRISQN AND ANDREWs 62. The total value of assets held by the 899 foundations included in the Twentieth Century Fund estimate was only $\$ 1,539,966,000$. Rucur AND DEARDORFF 11. The Twentieth Century estimate for 899 foundations is almost $\$ 300,000$ below the Russell Sage estimate for only 505 because the Twentieth Century Fund listed assets of only 240 foundations which reported their capital assets, ibid., while the Russell Sage Foundation included almost $\$ 400,000,000$ estimated assets of those foundations not reporting their capital assets. HARRISON AND ANDrews 57-8. The Russell Sage estimate included reported assets of only $\$ 1,431,553,417$ as reported by 265 foundations. Ibid. The 252 foundations included in the Tunks estimate reported assets in 1944 of $\$ 1,543,006,000$. Tunks 49 . And the latest estimate of the Sloan Foundation now places total foundation assets at about $\$ 2,000,000,000$. N.Y. Times, Aug. 17, 1949, p. 21, col. 1.

15. HARRISON AND ANDREws 62.

16. The first foundation embodying this ideal was the Peabody Education Fund, established in 1867 "for the promotion and encouragement of intellectual, moral, or indus" trial education among the young of the more destitute portions of the Southern and Southwestern States. ..." Tunks 23. See also Holuis, Pullanturopic Foundartons and Higher Education 32 (1938): "Peabody was the world's first philanthropist. . . [U]p to this time philanthropy was palliative; now it seeks to lay hold on the age to come."

The Peabody ideal did not spread effectively until 1896 when Andrew Carncgic be- 
manner, they act as constructive rather than palliative social forces. And absence of restriction in the original grants enables them to achieve flexibility in their choice of beneficiaries. ${ }^{17}$ The Carnegie foundations, for example, have supported projects by the Brookings Institute, the National Research Council and the American Law Institute. ${ }^{18}$ In such achievements the foundation has its principal justification.

Public spirit, however, is not the only motive for creating foundations. 10 Donors may be primarily interested in building or conserving private fortunes, or preserving family control over finance or industry. Accumulation and immobilization of wealth in privately controlled foundations will serve these ends. Donors can give vast sums to these foundations without encountering the heavy tax burden which would otherwise accompany such transfers, ${ }^{20}$ and the foundations, once created, receive continuing tax benefits. ${ }^{21}$

gan to establish his prototypes of the modern philanthropic foundation. Turks 28 . The Carnegie philosophy was to benefit the community by placing within its reach the ladders upon which the aspiring could rise. Carnegre, Gospel of IVEaztr 15 (Doubleday, Doran \& Co. ed. 1933) ; see also Harrison AND ANDEEws 21. And this philosophy has become the touchstone of most modern foundations. Id. at 96-S; RICIr AID DEAFLoRFF 15-17. The Rockefeller Foundation, for example, adopted the following criteria in choosing its beneficiaries: individual charity and relief were excluded; purely local applicants were excluded except where they could serve as models; local cooperation was a requisite; preference was given to activities which went to the heart of individual or social ill-being or misery; and projects were required to be well thought out and definite before presentation to the foundation. SEN. Doc. No. 415, 64th Cong., 1st Sess., v. 9 pp. $8139-41$ (1916).

17. The majority of foundations have broad charters, see ElLIOTr AND Crasmens, Charters of Philanthropies (1939), which permit sufficient fiexibility of purpose to enable them to change their programs of work to meet developing needs. Harniso:x Azid Andrews 38. The Rockefeller Foundation, for example, is organized "to promote the well-being of mankind throughout the world." Ibid. And among the foundation's criteria in choice of beneficiaries are the following: permanent obligations should not be assumed by the foundation; gifts in perpetuity should be avoided. SEx. Doc. No. 415, supra note 16 , at v. 9 p. 8140 .

18. Tunzs 30 .

19. Donors may be driven by a desire to spite legal heirs, see Tusks 144-5; preserve their names or memories, id. at $146-7$; win public approval, see KEPEL, TnE Foundation 18 (1930); Tunks 147; or atone for former misdeeds, see Ser. Doc. No. 415, supra note 16, at v. 1 p. 269 (recommendation by the Walsh Commission on Industrial Relations that the Rockefeller Foundation be terminated and its funds spent to relieve unemployment, sickness, and accident in labor's ranks, on the theory that the foundation's funds consisted of wages American workers should have received: "These wages were withheld by means of economic pressure, violation of law, cunning, violence practiced over a series of years by the founder and ... his business associstes."); Lindemcan, Wealth and Culture 5 (1936).

20. "The provision [of the estate tax statute] ... enables decedents to perpetuate, through charitable trusts and corporations, family control over their wealth without paying the estate tax." Hearings before Commitfee on Ways and Mcans on Revenue Revision of 1942, 77th Cong., 2d Sess. v. 1 p. 92 (1942) (statement of Randolph Paul, General Counsel of the Treasury); and see 1 PauL, Fedrral Estate axd Gmi Taxatio:i 646 n. 3 (1942). See also pp. $487-9$ and notes 148 and 149 infra.

21. INT. REv. Code $\$ \$ 101(6), 162(a)$. See pp. $489-91$ and notes 112 and $121-3$ infro.* 
Courts and legislatures, however, have made little effort to thwart uncharitable purposes of founders. Neither have they considered the effect: of foundations on concentration of wealth and economic power. ${ }^{22}$ The philanthropic foundation today remains relatively unregulated.

\section{FREEDOM OF FOUNDATIONS}

\section{Creation and Existence}

Foundations can be easily created and easily insulated against attacks on their legal existence. They may be created as trusts; ${ }^{23}$ they may also be incorporated under state statutes or special state or federal charters. ${ }^{24}$ While some state constitutions prohibit the granting of special charters, ${ }^{20}$ incorporation under general non-profit corporation statutes is permitted in all states. ${ }^{26}$ Charitable trusts, on the other hand, at one time were not recognized in Virginia, West Virginia and Maryland, ${ }^{27}$ and even now Virginia gives only limited recognition. ${ }^{28}$ Their validity was questionable in New York, Michigan, Wisconsin and Minnesota ${ }^{29}$ until those states passed

22. See pp. 489,490 and $497-500$ and notes $158-62$ infra.

Foundations have been subjected to several attacks on these grounds. The most notable of these attacks can be found in LindEMAN, WeALTH AND Culture (1936) and in the testimony of Louis D. Brandeis, SEN. Doc. No. 415, supra note 16, at v. 8 pp. 7663-4, and Samuel Gompers, Id. at v. 8 p. 7647, before the Walsh Commission on Industrial Relations in 1916. For counter-attacks see the testimony of Samuel Untermeyer before the Walsh Commission, Id. at v. 8 p. 7430-31; Harrison and Andrews 23; Furst, Philanthropic Endozments in 17 EncYc. BRITANNICA 712-13 (1938).

23. See, generally, 3 Scotr, TRusts $\$ \S 348,348.2$ and 348.3 (1939).

24. See, generally, Ballantine, Corporations $\$ 7$ (1946); 3 Scotr, Trusts $\$ 348.1$.

25. E.g., Mich. Const. Art. XII, §1.

26. E.g., Ill. ANN. Stat. c. 32, $\$ 163 a-163 a 100$ (Smith-Hurd, Supp. 1948). The only state which has an enabling act especially for foundations is Michigan. Mrcir. Stat. ANn. §21.164 (Henderson, 1935).

27. E.g., Trinity M. E. Church v. Baker, 91 Md. 539, 46 At1, 1020 (1900) ; Fificld v. Van Wyck's Ex'r, 94 Va. 557, 27 S.E. 446 (1897); Bible Society v. Pendleton, 7 W.Va. 79 (1873). The situation in these states resulted from repudiation of the British Statute of Charitable Uses, 1601, 43 Ez.IZ. c. 4, and the erroneous conclusion by the courts of these states that the Statute of Charitable Uses established the charitable trust. 3 Scorr, Trusts 1927; Tunks 182; Blackwell, The Charitable Corporation and the Charitable Trust, 24 WASH. U.L.Q. 1, 7-13 (1938). The charitable trust, in reality, antedated the Statute of Charitable Uses, which was nothing more than an expression of existing common law doctrine permitting the establishment of charitable trusts. 3 ScoTr, Trusts §348.2; TuNks 4-10, 182.

28. VA. CoDE $\S \S 55-26,55-27$ (1950) (limited to trusts for educational uses). Moore v. Perkins, 169 Va. 175, 192 S.E. 806 (1937). West Virginia and Maryland have given belated recognition. W. VA. CoDE $\$ \S 3501,3502$ (Michie, 1949) (did not become effective until 1931, Beatty v. Union Trust and Deposit Co., 123 W. Va. 144, 148, 13 S.E.2d 760, 762 (1941). MD. ANN. Code Art. 16, §279 (Flack, 1939) (became effective in 1931, Md. Laws 1931, c. 453).

29. E.g., Wheelock v. American Tract Society, 109 Mich. 141, 66 N.W. 955 (1896); Watkins v. Bigelow, 93 Minn. 210, 100 N.W. 1104 (1904); Ruth v. Oberbrunner, 40 Wis. 238 (1876). The uncertain status of charitable trusts in those states resulted from 
remedial legislation. ${ }^{30}$ The majority of foundations are therefore incorporated. ${ }^{31}$

Technically, creation of a foundation is simple. While creation of a trust by will necessitates compliance with all formal requirements for wills, ${ }^{32}$ an inter vivos trust may be created by conveyance, deed or declaration of trust. ${ }^{33}$ Even when a will sets forth charitable purposes inexpertly, equity will occasionally repair it. ${ }^{34}$ Establishment of testamentary trusts is further facilitated by refusal of courts to let a trust fail for want of a trustee. ${ }^{85}$ Corporations, in turn, can be organized under general state statutes by filing articles of incorporation with the secretary of state, 80 a procedure which is now a formality. ${ }^{37}$

Existence of a foundation, once created, may be attacked directly by the state, ${ }^{38}$ or collaterally by disinherited heirs, taxing authorities or tort claimants. ${ }^{39}$ A corporation need only file under the proper statute, albeit dethe omission in trust legislation during the nineteenth century of provisions for charitable trusts before the growth of foundations. See note 7 sipra; Tunss 184-6; Blaclwell, supra note 27 , at 13 .

30. N.Y. Pers. Prop. Law § $12 ;$ N.Y. Real Prop. Law $\$ 113$. These provisions were passed in 1893 as the Tilden Act, N.Y. Laws 1893, c. 701, Blackwell, supra note 27, at 14, after invalidation of the $\$ 5,000,000$ Tilden trust in 1891. Tilden v. Green, 130 N.Y. 29, 28 N.E. 880 (1891) (in absence of statute validating charitable trusts, Tilden trust failed for want of a definite beneficiary, whereas charitable trusts, when recognized, do not require definite beneficiaries). The Tilden Act validated charitable trusts for uncertain beneficiaries, but did not permit perpetual charitable trusts. Blackwell, supro note 27, at 15. Mlichigan's statute, passed in 1907, Mfich. Acts 1907, No. 122, is a replica of the Tilden Act, save for a provision authorizing perpetual charitable trusts. Mirca. Sicr. ANN. \$26.1191 (Henderson, 1935). Wisconsin and Minnesota also passed imitations of the Tilden Act in 1917, Wis. Laws 1917, c. 170, and 1927, Mfinn. Laws 1927, c. 180, respectively. The Wisconsin law contains no authorization for perpetual trusts, Wrs. STat. \$231.11 (1947), while the Minnesata law does. MIrNs. STAт. Arss. \$501.12 (1945).

31. Of 183 foundations investigated as of 1944, 121 were incorporated (92 under general statute and 29 under special legislative charter) while only 62 were established as trusts. Tunrs 181. Charitable trusts are noticeably scarce in Virginia, West Virginia, Maryland, New York, Michigan, Wisconsin and Mfinnesota. Of the 62 trusts investigated as of 1944, none was established in Virginia, West Virginia or Mfaryland, id. at 183; only 4 were established under New York law as perpetual trusts, thereby risking invalidation (see note 30 stpra), Tunks $185 ; 5$ were established in Mfichigan after 1907 (see note 30 supra), TuNks 186; and none was established in Wisconsin or Minnesota. Ibid.

32. 3 Scott, Trusts $\$ 357$; Remsen, Post Miortear Use of Wenlta 3-85 (1911).

33. 3 SCOTT, Trusts $\$ 349$.

34. See Tunks 201.

35. 3 Scotr, Trusts $\$ 397$; Tunks 201 ; e.g., Jeffreys v. International Trust Co, 97 Colo. 188, 48 P.2d 1019 (1935).

36. E.g., InL ANN. Stat. c. $32 \S \S 163 a 27-163 a 30$ (Smith-Hurd, Supp. 1948). See TUNKS 187.

37. See Tunrs 187.

38. See, generally, Ballantine, Corporations $\$ 23$ (1946).

39. See Tunks 187.

These three classes are the only ones likely to contest the existence of a charitable 
fectively, to render itself immune from collateral attack. ${ }^{40}$ It is open to direct attack for defects in filing; ${ }^{41}$ but such defects may be cured by amending the articles of incorporation. ${ }^{42}$ A trust can be attacked with success, directly or collaterally, when the declaration of trust fails to specify "charitable" beneficiaries. ${ }^{43}$ Moreover, if such failure occurs, the declaration cannot be amended; ${ }^{44}$ and establishment of a new trust may be impossible or unavailing.

Direct attacks, however, almost never occur. ${ }^{45}$ And careful draftsmanship can immunize all foundations from any attack, since courts look not to the intent of the donor nor to the accomplishments of his foundation, but only to the formal purposes stated in the document creating the founda-

corporation: disinherited heirs, because they take by intestate succession if there is no corporation to take under a will; taxing authorities, because they can not tax a charity or transfers to a charity, see pp. 486-91 and notes 73-6 infra; and tort claimants, because charities are usually immune from tort liability. Ballantmane, Conporations 28 (1946).

40. When a corporation is thus immunized from collateral attack it is said to lave de facto existence. Essentials for recognition of de facto corporate existence are four:

(1) A valid statute under which the corporation in question could have been formed.

(2) Colorable compliance with that statute.

(3) Transaction of business in some way as if the corporation in question was a corporation.

(4) Good faith in claiming to be a corporation, and fairness between the partics under the circumstances.

Batlantine, Corporations $\$ 24$ (1946). See also Tunks 187. Recent state enabling acts provide specifically for de facto existence. E.g., Ill. Stuts. ANv, c. $32 \& 163 a 30$ (Smith-Hurd, Supp. 1948).

41. Against direct attack, the corporation must show de jatre existence. And substantial compliance with the mandatory provisions of the incorporation statute is required to show de jure existence. Ballantine, Corporations 76 (1946). See also Tunks 187-8.

42. E.g., Ir.. Stat. ANv. c. $32 \S \S 163 a 32-163 a 36$ (Smith-Hurd, Supp. 1948); see Tunks 190. See also note 52 infra.

43. E.g., Chichester Diocesan Fund v. Simpson [1944] A.C. 341 (testamentary trust for charitable institutions or "other charitable or benevolent . . . objects" as trustec may" select, held invalid). In the Chichester case, the House of Lords found, first, that the testator intended to permit the trustee to spend trust funds on purposes which were not "charitable" if he so chose; and, second, that such a trust was invalid as a perpetual trust since it was not exclusively "charitable". See notes 59-61 and 63 infra. The pitfall in the Chichester case was the use of the word "benevolent", a word traditionally frowned upon by courts as not coming within the classic "charitable" ficlds of poverty, health, education and religion. Morice v. Bishop of Durham, 9 Ves. 399 (Ch. 1804), 10 Ves. 522 (Ch. 1805) ("such objects of benevolence and liberality," held not "charitable").

The doctrine of the Morice case has been generally adopted in America. E.g., Read v. McLean, 240 Ala. 501, 200 So. 109 (1941); see Scott, Trists for Charilable and Benevolent Purposes, 58 Harv. L. Rev. 548, 551 n. 10 (1945). Contra: Goodale v. Mooney, 60 N.H. 528 (1881).

44. See Tunks 190.

45. Tunks 188; see notes 55-8 infra. 
tion. ${ }^{46}$ If the purposes stated in the articles of incorporation fulfill the broad requirements of the incorporating statute, or if those in the trust indenture state a "charitable" end, the foundation's existence is invulnerable to attack.

\section{Operation}

After its establishment, the foundation is subject to little public control. Although trustees may be personally liable to the trust or its beneficiaries for failure to invest trust funds "prudently" or in legislatively "approved" investments, ${ }^{47}$ such liability may have been ruled out by the settlor. ${ }^{19}$ Corporate directors are generally immune from personal liability in the absence of bad faith. ${ }^{49}$

Proceedings for specific performance, rescission or reformation afford, in theory, greater opportunities for public control. They may be instituted

46. See 2 Bogert, Trusts and Trusters $\$ 364$ (1935); 3 Sootr, Trusts 1974 and 1974 n. 4 ; TunKs 155-6, 190; see Vidal v. Girard's Executors, 2 How. 126, 197-S (U.S. 1844); Matter of Frasch, 245 N.Y. 174, 182, 156 N.E. 656, 658 (1927). See also note 83 infra.

47. 2 Scotr, Trusts \$227. Many states provide lists of "approved" investments; some lists are extremely conservative. Id., \$227.13. Some statutes prohibit deviation from the list without specific authority from the court or settlor. E.g., FLA. Sт八т. Aws. $\$ 518.01$ (1943) ("may invest... . only in the following:"); LA. GEN. STAT. \$9850.62 (Dart, 1939) ("shall invest ... only in the following. ..."). Some are permissive. E.g., ALA. CoDE tit. $58 \$ 47$ (1940) ("may, . . . in addition to any other investments now permitted by law, invest. . ."); ARK. STAT. ANN. c. 58-103 (1947) ("It shall be lawful ... to invest. ...”). See, generally, 2 Scors, Trusts \$227.13; Comment, Legal Lists in Trust Investment, 49 YALE L.J. 891, 896-9 (1940). Investments permitted by such statutes must be "prudently" selected in most states even though they fall within an "approved" class. 2 Scotr, Trusts $\$ \$ 227.12$, 227.13; RestATEarent, Trusts $\$ 227$, comments $m$ and $p$ (1935); Legis., 49 HARv. L. Rev. 821,823 (1936); c.g., Campbell v. Albers, 313 Ill. App. 152, 165-6, 39 N.E.2d 672, 679 (1942). And, of course, investments not specifically enumerated in permissive statutes and investments in states which do not have "approved" lists must pass the judicial test of prudence. See, generally, 2 Scotr, Trusts \$227. For judicial criteria of prudence, see, generally, 2 Scort, Trusts \$\$227.1-227.11. Some states, moreover, have established the "prudent man" formula by legislation. E.g., CAL. Crv. CoDE $\$ 2261$ (Deering, 1949).

48. See, for example, note 132 infra. Legislation limiting trust investments always leaves room for provisions by the settlor absolving trustees from liability for failure to invest in legislatively approved investments. E.g., LA. GEN. STAт. \$9850.62 (Dart, 1939) ; Car. Civ. Code \$2261 (Deering, 1949). See, generally, Restateurent, Trusts $\$ 227$ (1935) ; 2 Scotr, Trusts 1226; Tunrs 197-8.

49. Restrictions upon corporate directors flow from corporate statutes rather than trust doctrine and therefore are rarely stringent. TuNrs 198. But some states have subjected charitable corporations to the same lists of "approved" investments to which they have subjected trusts with personal liability imposed upon directors for losses resulting from deviation from such lists. E.g., ORE Courp. Laws Awn. \$73-103 (1940).

$\mathrm{Bad}$ faith is a ground for liability on the part of trustees as well as directors. And the settlor of a trust cannot rule out such liability, since an attempt to do so would be against public policy. Restatenrent, Trusts $\$ 222$, comment $b$ (1935); 2 Scort, Trusts $\$ 222.3$; e.g., Carrier v. Carrier, 226 N.Y. 114, 125-7, 123 N.E. 135, 138-9 (1919). 
to compel contribution by the foundation to its beneficiaries; ${ }^{50}$ to remove trustees or corporate directors for abuse of discretion; ${ }^{61}$ or to reform trust indentures when fulfilment of their terms has become impossible or impracticable. ${ }^{52}$ But in practice these remedies are rarely invoked. Since beneficiaries of most foundations are indefinite, ${ }^{53}$ suits to compel contribution or to remove trustees or directors must usually be brought by state attorneys-general. ${ }^{54}$ Attorneys-general are usually uninformed ${ }^{66}$ and un-

50. 3 ScoTt, TRUSTs $\$ \$ 391,392$.

51. 3 Scotr, Trusts \$387; Tunks 201 and 357 n. 96.

52. Such reformation is granted by the courts under the doctrine of cy pres. Considerable emergency must be shown to warrant application of the doctrine, i.c., that the trust funds are insufficient to accomplish the stated object; that the funds are excessive for accomplishing the object; or that changing events have made accomplishment of the object impossible. 2 Bogert, Trusts aNd Trustees $\S 438$ (1935). Application of the doctrine is further restricted by the requirement that if the stated charitable intent fails, a general charitable intent must be found in the trust to warrant modification of the instrument to fulfill unstated charitable purposes. Id., $\$ 436$. A final limitation of the doctrine is that it is not in force in approximately 7 jurisdictions. Id. at 1297-8. See, generally, Tunks $243-5$; 3 Scotr, Trusts $\$ \$ 399-399.4$.

Charters of charitable corporations, however, are never amended in court. Statutes usually provide for their amendment, when necessary, by corporate directors. See note 42 sipra.

53. See 3 Scort, Trusts $\$ \S 364,375$. See also note 17 supra.

54. Restatement, Trusts $\S 391$, comment $a$ (1935) ; 3 Scotr, Trusts 1967; Note, State Supervision of the Administration of Charitable Trusts, 47 CoL. L. REv, 659, 661 (1947). Attorneys-general are empowered to sue on the theory that they represent whole classes of indefinite beneficiaries. 2 Bogert, Trusts and Trustees 1259 (1935); Note, State Supervision of the Administration of Charitable Trusts, 47 CoL. L. REv. 659, 661 (1947). Would-be beneficiaries, because they are indefinite, are unqualified to sue the trustees. E.g., Averill v. Lewis, 106 Conn. 582, 138 Atl. 815 (1927) (where trust was to provide home for white Protestant female teachers of a certain county, 110 such teachers who were possible beneficiaries of the trust had no status to appeal from an accounting decree establishing the corpus of the trust; only the Attorney-General could appeal). Such restrictions on suits by would-be beneficiaries is the result of a desire to save trustees from frequent, vexatious suits based on inadequate investigation, and brought by irresponsible parties. 2 Bogert, TRUSTS AND TRUSTEES 1259 (1935).

55. The most common form of statute providing for availability of trust information to attorneys-general requires all trustees (private and charitable) to file periodic accounts after the settlor's death, usually with a probate court, c.g., Conn. Gen. Stax. $\$ 7052$ (1949); Onio Code ANN. \$10506-34 (Page, 1937); or equity court, c.g., Dei. REv. CODE, $\$ 4400$ (1935). These statutes do not require accountings by inter vivos trustees. A few states provide specifically for accounting by all charitable trustees. E.g., Ind. Stat. Ann. §7-714 (Burns, 1933); N.C. Gen. Stat. §36-19 (1943). And only a few others require charitable corporations to report annually to the secretary of state. E.g., Mrch. Stat. ANn. $\$ 21.81$ (Henderson, 1935) ; Ill. ANn. Stat. c. 32 \$163a63 (Smith-Hurd, Supp. 1948). Where requirements of reports do exist they request little information. See, for example, the Illinois statute on corporate reports which is the most recent and the most detailed. InL. Ann. Stat. c. $32 \S \$ 163 a 63$ and 163a98. And sce Tunks 297-8.

Moreover, in no state are foundations required to report directly to the attorney- 
derstaffed. ${ }^{56}$ As a result they bring few such suits. ${ }^{57}$ Nor do they often sue to reform trust agreements. ${ }^{53}$ The freedom of charitable foundations to operate as they please is virtually complete.

\section{Duration}

The most important freedom extended to founders is the power to make their "monuments" permanent. The Rule against Perpetuities, adopted by all states, ${ }^{59}$ requires that transferred interests vest absolutely in some person within a stated period of time, usually measured by a life or lives in being and 21 years. ${ }^{60}$ The ordinary trust must be terminable within the period required by the rule. ${ }^{61}$ Because of the supposed desirability of providing security for charitable beneficiaries, ${ }^{62}$ however, charitable trusts can be set up to last forever. ${ }^{63}$ Transfers to charitable corporations escape the Rule

general; thus, foundation failure to file a report may easily escape his notice See Bushnell, Report and Recontmendations for Legislation, MLAss. L.Q., Miay, 1945, p. 22, at 24, 28; Note, State Stipervision of the Administration of Charitable Trusts, $47 \mathrm{CoL}$ L. Rev. 659, 663 (1947); D'Amours, Control of Charitable Trusts, Regular Stupercision by Attorney General Urged, Journal of Capital Trusts and Estates, March 1947, p. 345.

56. See Statement of CIO and TWUA before R.I. Cozrar. on Charrsable Trusts 11 (1949). Bushnell, Report and Reconmendation for Legislation, MLass. L.Q., Miay, 1945, pp. 22, 26-7 (1945); Note, State Supervision of the Administration of Charitable Trusts, 47 CoL. L. Kev. 659, 663 (1947); see Souhegan Nat. Bank v. Kenison, 92 N.H. $117,122,26$ A.2d 26, 30 (1942): "But the [attorney-general's] office is unorganized and unequipped to enforce such trusts in a comprehensive scheme under supervisory arrangement. The result is that the office acts only in sporadic instances. ..."

57. CiO and TWUA Statenent Before R. Spec. Comas. on Canartanele Trusts 11 (1949). See also Bushnell, Report and Recommendation for Legislation, MLnss. L.Q., May, 1945, p. 22 at 27 (1945); Note, State Supervision of the Administration of Charilable Trusts, 47 CoL. L. Rev. 659, 662-3 (1947).

58. See note 57 sipra. Admittedly, trustees themselves may demand reformation of trusts, 2 Bogert, Trusts AND Trusters $1331 \mathrm{n} .8$ (1935), but the necessity for resulation arises precisely because many trustees fail to institute reformation proceedings.

59. Leach, Perpetuities ish a Nutshell, 51 HARv. L. Rev. 638, 639 (1938). The rule in approximately two-thirds of the states is a common law rule. In the remaining states the common law rule has been modified to varying extents by statute. Ilid. For an analysis of state legislation see 2 Sines, Future InTERests c. 32 (1936).

60. Standard statements of the rule may be found in GraY, TuE RuLE Acanist Perpeturties 191 (4th ed. 1942); 2 Sintes, Future Interests $\$ 490$ (1936).

61. See 1 Bogers, Trusts and Trustees 639 (1935); 2 Siares, Futune Imterests $\S 553$ (1936).

62. See 2 Stares, Future Interests $\$ 554$ (1936); Zollunan, Aurepicast LAv of Charities $\$ 530$ (1924); see In re Browning's Estate, 165 Mrisc. 819, 827-9, 1 N.Y.S. 2d 825, 832-3 (Surr. Ct, 1938), aff'd, 281 N.Y. 577, 22 N.E. $2 d 160$ (1939).

The opposite viewpoint is expressed in Rosenwald, Principles of Public Giving, 143 ATL MoNthly 599 (1929) (classic argument against perpetual foundations by founder of Julius Rosenwald Fund, a foundation which was self-liquidating within 25 years), and in Anthony, Should Endoaments Be Perpetual? in Trusts AND TRUstersarps 96 (Anthony ed., 1932). See also notes 166-S infra.

63. 3 Scott, Trusts $\$ 365 ; 2$ Stnses, Future Interests $\$ 554$ (1936); Zollssan, 
against Perpetuities by grace of a legal fiction. The corporation is in law a "person," infinite though its life may be, and since interests transferred vest absolutely in the corporation, the rule is satisfied.

An additional boon to perpetual existence of charitable trusts comes from the ability of donors to prevent transferees from distributing the principal. Restrictions of this kind cannot be put on transfers for private purposes: direct "restraints on alienation" are forbidden. 64 But again, because of the supposed desirability of encouraging charitable transfers, the general rule has not been applied to restraints upon transferees for charitable purposes. ${ }^{0 t}$ Founders usually take advantage of this exception: the majority of foundations are now prohibited by their founders from spending any of their principal funds. ${ }^{66}$ And even where founders have permitted expenditures of principal, trustees and directors often refrain from such action anyway."7 The overwhelming majority of American foundations tend toward immortality.

\section{Tax Privileges for Charity}

Over and above their comparative freedom from public regulation, philanthropic foundations and their founders have enjoyed freedom from federal and state taxation. This kindliness is justified primarily on the ground that foundations fill a public need which the government would otherwise be obligated to fill, ${ }^{68}$ and that this public need is better served by

op. cit. supra note $62, \S 530$; e.g., Camp v. Crocker's Adm., 54 Conn. 21, 5 Atl. 604 (1886).

64. 2 Simes, Future Interests, $\$ \$ 441-4$ (1936). Like the Rule against Perpettitics, the rule against direct restraints upon alienation is a common law rule modificd to varying degrees in a few states. $I d$., c. 32 .

65. E.g., Trustees of First Presbyterian Church v. Wheeler, 149 Atl. 589 (N.J. Cl. 1930) (devise of land to church with provision that land not be sold except in future emergency, held valid). See Tunks 227-8; 40 YaLE L.J. 143 (1930).

66. Of 124 foundations investigated as of 1944,72 with assets of $\$ 616,489,000$ (42 corporations and 30 trusts) were legally forbidden to spend principal, while 52 with assets of $\$ 478,974$ (32 corporations and 20 trusts) were permitted by their founders to spend principal. Tunks 230. See also Note, The Use of Charitable Foundations for Azoidance of Taxes, 34 VA. L. REv. 182, 198 (1948).

67. Of the 52 foundations investigated in 1944 which were permitted by their founders to spend principal, see note 66 supra, 13 corporations with assets of $\$ 81,897,000$ and 7 trusts with assets of $\$ 76,433,000$ appeared never to have spent any of their principal funds; eleven corporations with assets of $\$ 242,967,000$ and 7 trusts with assets of $\$ 24,833,000$ appeared to have spent principal; and information could not be confirmed as to whether 14 , with assets of about $\$ 50,000,000$, had or had not spent principal. TUNXs 231-2.

68. "The exemption from taxation of money or property devoted to charitable and other purposes is based upon the theory that the Government is compensated for the loss of revenue by its relief from financial burden which would otherwise have to be met by appropriations from public funds, and by the benefits resulting from the promotion of the general welfare." H. R. Rep. No. 1860, 75th Cong., 3d Sess. v. 1 p. 742 (1939-1 Cum. Bull., Part 2, 742). See also 1 Paul, Federal Estate and Gift Taxation $\$ 12.04$ (1940); Tunks.286-7; Bradway, New Uses for Wealth as Endouments, 151 AnNals 
private foundations than by government. 9 Two classes of tax immunity are embraced in this field: one for the founder and one for the foundation. Founders, as donors of charity, can claim statutory deductions from estate, inheritance, gift, and income taxes, while foundations are granted statutory immunity from virtually all income and property taxes.

\section{Founder Deductions}

Federal estate and gift taxes, as well as state inheritance taxes, 70 are graduated progressively, with very high rates on transfers of large sums of wealth. ${ }^{71}$ The dual purpose of this scheme is to base the tax on ability to pay, and to prevent complete transfer of great concentrations of wealth

184 (1930) ; Lynch, The "Charities" Provisions of the Internal Revenue Code, 10 Fosd. L. REV. 234, 250 (1941).

69. See Eliot, Exensption frons Taxation in alíssachusetts 2l-45 (1910); Shoup, Tax Exemption in 14 ENcyc. Soc. ScI 528, 530 (1934); Schultz, Death Tas Esemptions in Tax Exexrptions 107, 118 (Tax Policy League, 1939); Killough, Exemptions to Education, Philanthropic and Religious Organizations in id. at 23-38; Mrartin, General Theory of Tax Exemptions in id. at 3, 17; N.Y. Times, Aug. 17, 1949, p. 21, col. 1 (statement by Sloan Foundation); see In re Browning's Estate, 165 Mlise 819, 829, 1 N.Y.S.2d 825, 833 (Surr. Ct, 1938), aff'd, 281 N.Y. 577, 22 N.E.2d 160 (1939) ("The salvage of the American ideal will be difficult if the principle of subsidy overshadows the principle of private charity. There is reason now to approve charitable foundations as serving the public good because they restore to better balance the relationship of the individual to his government. To the extent of its resources, private charity vill remove the temptation of the underprivileged to regard government as obliged to furnish support and will aid in the restoration of a sense of personal responsibility among its donees. Such private funds are not subject to bureaucratic administration. They never lose their character as true charity.").

The opposing viewpoint is expressed in Wengwood, Tue Econosncs of Iruenitaricz 91 (1929) : "[I]t has been obvious, at least since the days of the Tudors, that, from the fiscal point of view, taxation is a more satisfactory expedient than exhortations to private benificence. It is also certain that it is likely to be a more efficient method of reducing inequality than the encouragement of philanthropic bequests." See also Knapp, Tax Exemptions, address reported in Proceedings of Natronal TAx Assocrationi 74 (1934).

70. Since the Federal government allows a credit up to 80 per cent of the basic federal estate tax for inheritance, legacy, succession, or estate taxes imposed by the states and the District of Columbia, INr. Rzv. Cove $\$ 813(\mathrm{~b}), 47$ states and the District of Columbia now impose inheritance taxes sufficient to take advantage of the 80 per cent credit. The state statutes are collected in TAX Systems 238-46 (1948). See Tumzs 252-3.

71. INT. REv. CODE $\$ \$ 810, \$ 60$ (basic estate tax rates); for state tax rates see TAx Systears 238-46 (1948). The additional estate taxes of 1932 and 1949 illustrate the extreme graduation which has always been an essential feature of the estate tax system:

\begin{tabular}{|c|c|c|}
\hline Net Estate & & \\
\hline $\begin{array}{r}\$ 100,000 \\
500,000 \\
1,000,000\end{array}$ & $\begin{array}{r}1932 \\
\$ 5,000 \\
49,000 \\
126,000\end{array}$ & $\begin{array}{c}1949 \\
\$ 20,700 \\
145,700 \\
325,700\end{array}$ \\
\hline
\end{tabular}

Revenue Act of 1932, §401, 47 StAT. 243 (1932); INT. Rev. CODE $\S 935$. 
from one generation to the next.72 But since charitable gifts, no matter what their size, inure in theory to the benefit of charity, testamentary gifts to foundations are deductible by executors and administrators in computing net taxable estates under the federal estate $\operatorname{tax}^{73}$ and state inheritance tax laws. ${ }^{74}$ Similarly inter vivos gifts to foundations are not subject to the federal gift tax on inter vivos transfers. ${ }^{75}$

The tax savings available to founders extend beyond the estate and gift tax deductions. In computing their net income for federal and state income taxes, founders may deduct charitable gifts up to 15 per cent of their gross income. ${ }^{76}$ Here again, while net income taxes are graduated progressively, ${ }^{77}$ the deduction is allowed no matter how large the donor's income may be, since the gift in theory goes to charity.

Thus, when foundations are created by testamentary or inter vivos gifts, or by annual contributions by the founder out of income, or by both, the government is a major contributor. Gifts to foundations are usually large 78 and they come from donors in high income tax brackets..$^{79}$ Much of the funds

72. "But revenue alone is not the sole reason for the enactment of the Federal death duty. There have been in this country for many years warm adherents to the belief that something must be done to discourage rapid growing fortunes, that some limit must be placed upon the possibility of a few individuals acquiring so much money that the Government itself is menaced by the power it brings them." Roper, Taxation ProblcmsII Who Should Pay the Taxes?, 222 N. Am. Rev. 12, 13 (1925). See also H.R. Rep. No. 1681, 74th Cong., 1st Sess. 2 (1939-1 Cuns. Burc., Part 2, 643) (message of President Roosevelt to Congress, June 19, 1935); Hearings before the Sente Finance Commiltee on H.R. 8974 74th Cong., 1st Sess. 177-8 (1935) (testimony of Robert H. Jackson, Ass't. Gen. Counsel, Treas. Dept. (now Mr. Justice Jackson)). For a thorough disctussion of the problem and numerous citations see 1 PaUd, Federar Estate and Gift Taxation $\S \S 1.02,1.07$ (1942).

73. INT. REv. CODE $\$ 812$ (d).

74. E.g., Colo. Stat. c. $85 \S 26$ (c) (1935). Some states exempt charitable trangfers from their inheritance tax instead of allowing a deduction for such transfers. E.g., Ind. Stat. ANv. § 6-2403 (Burns, 1933).

75. INT. REv. CODE $\$ 1004$ (a) (2) (B).

76. INT. REv. CODE $\$ 23(0)$ (individual deductions up to 15 per cent). Corporations are legally permitted to establish foundations but have never done so. They frequently contribute to foundations out of income, however, and are allowed only a 5 per cent deduction for such contributions. INT. REv. CODE $\$ 23(q)$.

Of the 35 states and the District of Columbia which have personal or corporate income taxes, only two, Idaho and Montana, do not allow deductions for charitable contributions. Tunks 263 and $369 \mathrm{n}$. 16. Twelve states impose a limit on individual deductions smaller than the 15 per cent limit found in Section 23(o) of the Internal Revenue Code. Tunks 369 n. 16; e.g., N.C. Gen. Stat. \$105-147 (Michic, 1943) (10 per cent limit). And 10 states allow a larger limit on corporate deductions than the 5 per cent limit found in Section 23(q) of the Code. Tax Systems 137-8 (1948); e.g., N.D. Cope § 57. 3822 (1943) (15 per cent limit). All the state statutes are collected in TAx Systems 128-34 (1948).

77. E.g., INT. Rev. Code $\$ 12(b)$. See also notes 71 and 72 supra.

78. See notes 5 and 7 supra.

79. See notes 5-7 supra. 
which go to foundations tax-free would ordinarily be collected by the government in taxes. ${ }^{83}$

Presumably these deductions should be available only if the gift is for a public purpose. Despite ample evidence, however, that foundations which receive transfers often are used by their founders to build or conserve private fortunes, or to preserve family control over finance or industry, ${ }^{81}$ these factors have never been used as a basis for denying the estate, gift or income tax deduction. ${ }^{82}$ The Treasury has failed to explore the possibilities of such an attack, perhaps because courts have indicated that they would refuse to investigate the actual achievements of foundations. As long as foundation principal or income is not payable or paid to private beneficiaries, words of "charitable intent" in a foundation instrument appear to be enough to render contributions to such a foundation deductible..$^{83}$

\section{Foundation Immunity}

State and municipal property taxes impose some burdens on charitable institutions. For example, in order to protect the revenues of towns and cities where private schools and churches own most of the land, several states provide for taxation of realty held by charities for investment purposes. ${ }^{84}$ Foundation investments, however, are usually in personal rather than real property, ${ }^{85}$ and personalty is almost always exempt. ${ }^{\varepsilon s}$

But the most important tax benefit enjoyed by foundations is the immunity from the federal income tax provided in Sections 101(6) and 162(a) of the Internal Revenue Code. Section 101(6) exempts from taxation all corporations, funds or foundations "organized and operated exclusively for religious, charitable, scientific, literary, or educational purposes, or for the prevention of cruelty to children or animals." The Treasury originally sought an interpretation of this section which would have disqualified institutions engaging in any business activities. But the Supreme Court re-

80. See Griswold, Cases on Federal Tasation 286 (2d ed. 1946); Mo:ticosremY and Wynn, Federal Taxes-Estates, Trusts and Gifts 28-31 (1948-9); 1 Pauh, Federal Estate and Gifx Taxation $\$ 12.28$ (1942); Tunks 260-62.

S1. See pp. 497-501 and notes 142-54, 158-62 infra.

82. See Tunks 264.

83. In A. W. Mellon, 36 B.T.A. 977, 1048, 1064-6 (1937), the A. W. Mfellon Edueational and Charitable Trust was held a proper recipient of income tax-deductible gifts, though rare paintings supposedly donated to it remained in possession of the Miellon family. The court looked only to the charitable intent as stated in the foundation instrument. See Tunzs 264 and 342 n. 28; N.Y. Times, Aug. 29, 1937, p. 1, col. 1. And the Mellon Trust also received free of the estate tax a substantial estate, estimated at about $\$ 100,000,000$, from A. W. Mellon at his death. See Griswold, Cases on Federni TaxATION 286 (2d ed. 1946). See also notes 46 supra and 89 infra.

84. E.g., Ill. Rev. Stat. c. $120 \$ 500$ (Smith-Hurd, 1936); N.Y. TAX LAV $\$ 4$ (1948).

85. See note 3 sipra.

86. See Tunks 283 ; e.g., N.Y. Tax Law $\$ 3$ (1948). 
fused to accept the Treasury's view. An institution is operated for a charitable purpose as long as the "ultimate destination" of the entire business income is a charitable cause. 87

The trust form of institution picks up an additional tax privilege in Section 162(a). Though the trust engages in non-charitable pursuits, it may deduct from taxable gross income any part of its income spent or set aside permanently for charitable purposes pursuant to the terms of the trust instrument. Should it so dispose of all of its income, the trust gains complete exemption under either 162 (a) or 101(6).

It would seem, moreover, that the 101(6) exemption for all forms of socalled "charitable" foundations is available even though the main motive of the founder was private'rather than public. The Treasury has never attempted to challenge a 101(6) exemption with the argument that the foundation was being used primarily to preserve a private fortune, and if made the attempt would probably fail. Courts are likely to follow their past procedure ${ }^{88}$ and refuse to investigate the actual accomplishments of the foundation. Wherever they find provisions of general charitable intent precluding payment of principal or income to private beneficiaries, courts may quickly conclude that the foundation was "organized . . . exclusively for ... . [a] charitable ... purpose. . . ." 89

There is a more definite limitation on both 101(6) and $162(\mathrm{a})$, but it probably has little practical significance. If a founder should retain legal control of his foundation over and above the normal control which he may

87. Trinidad v. Sagrada Orden de Predicadores, 263 U.S. 578 (1924). The Board of Tax Appeals extended the Trinidad holding to its logical extreme in Sand Springs Home, 6 B.T.A. 198 (1927) (old folks home operated a cotton gin, had oil and gas leases, sold oil and gas, generated electricity, sold water to the public, and owned and operated an amusement park; most of the home's income was ploughed back into business each year; the home's income was held completely tax exempt). The Burcau of Internal Revenue acquiesced in the decision, VI-1 Cum. BuLl. 5 (1927). Morcover, no case has been found denying exemption under Section $101(6)$ to a foundation engaged in business. Tunks $273-4$.

As a result of these holdings, charities have gone into all sorts of business, often to the advantage of private individuals or corporations with which they deal. See note 113 infra. Today charitable and educational organizations have a larger income from business activity than any of the other 18 groups of tax-exempt organizations except cooperatives. Fortune, Aug., 1947, p. 108, 140, col. 2.

As a partial remedy for this situation, Representative Mason has introduccd a bill in Congress to remove the tax exemption now extended by the Supreme Court interpretation of Section 101(6) of the Internal Revenue Code to business income of all charitable organizations. H.R. 5064, 81st Cong., 1st Sess. (1949). In defining "business income," the bill specifically excludes interest and dividend income received by charitable organizations. For doubts as to the advisability of such a remedy, see note 165 infra.

88. See note 83 supra.

89. Similar stress has been placed upon the language of trust indentures in cases aristng under Section 162(a). E.g., Bank of America v. Commissioner, 26 F.2d 48, 51 (9th Cir. 1942). See Hearings before Subcommittee of Committec on Intcrstate and Foreign Commerce, U. S. Senate, 80th Cong., 2d Sess. 726-31 (1948) (testimony of Claude R. Branch and Senator J. Howard McGrath). 
exercise as a trustee, the foundation's incorne will be taxed to the founder as ordinary personal income. ${ }^{\$ 0}$ Founders rarely make this mistake, however. In establishing charitable trusts they often appoint themselves sole trustees and thereby retain all the control they need without jeopardizing any of the trust's tax privileges. When they establish corporations, which are more prevalent than trusts, founders usually retain effective control on an informal basis.91 And informal control is no ground for denying the foundation's tax deductions or exemptions. ${ }^{22}$

90. The income of such a foundation is taxed to the founder on the theory that he never parted with the income-producing wealth. Similarly, founders are not entilled to income tax deductions for contributions to such foundations. If the founder still controls the property, obviously he is unable to take a deduction for giving it away. Some of the provisions denying tax privileges to foundations legally controlled by their founders are legislative, INT. REv. CODE $\$ 166$, and some are administrative. U.S. Treas. Reg. 111, $\$ 29.22(a)-21$ (1947). They were not passed to limit foundation tax privileges. Primarily, they are designed to prevent wealthy taxpayers from splitting thcir income among trusts which they control, and thereby decreasing the total tax payable on such income through payment of lower surtaxes on each portion of the split income. To the extent that founders retain the type of control specified in these provisions, they are affected indirectly by the provisions.

The control specified in Section 166 of the Internal Revenue Code is retention by the grantor or any person not having a substantial adverse interest in the trust of the power of revocation. The following controls specified in Treasury Regulation 111, $\$ 29.22$ (a) -21 are pertinent to foundations: retention by the grantor or anyone not havins a substantial adverse interest in the trust of the power to buy charity assets in a preferential manner; to borrow from the trust without interest, security or a provision for repayment within one year; other than as trustee, to vote stock lield by the trust, control trust investments, or substitute different investments for those held by the trust.

91. Of 55 foundation board members questioned several years ago, 30 , including 10 who said so emphatically, believed in strict adherence to the wishes of the founder in administration of the foundation; 11 were undecided; and 14 did not belicve in such adherence, 7 of them strongly. Coffman, Axierican Foundations 166, 167, 169 (1936). Andrew Carnegie and John D. Rockefeller exercised strong informal control over the boards of their foundations. See Carnecte InStrtute of Wasmington, Yenrcoor 503 1919 10-11 (Pres. Woodward's report: "Thus, to cite a single example, which illustrates his characteristic frankness and fairness, shortly before the construction of the non-magnetic ship was authorized ... he ... [remarked], 'I don't approve that project you are urging for a non-magnetic ship. But,' he added, 'maybe I don't understand it?' The opportunity thus gracefully extended was speedily utilized and MIr. Carnegie was readily convinced that the project in question was not one merely of an enthusiastic dreamer, but one based on the carefully verified ... plans of competent engineers."); RockerezuER Foundation, ANNUAL REPORT FOR 1915, p. 333 ("at the suggestion of the donor," holdings in the Colorado Industrial Company were traded for Virginia-Carolina Chemical holdings) ; SEN. Doc. No. 415, 64th Cong., 1st Sess., v. 8 p. 7776 (1916) (testimony of John D. Rockefeller, Jr.: "Our office staff is a sort of family affair. We talk over all linds of matters of our common interest. We have not drawn sharp lines between business and philanthropic interests."). The stock voting histories of large foundations indicate that they vote their stock with the interest of the founder's family. See BerLe a:id AfEars, The Modern Corporation and Private Property 82-3 (1932); Tunks 115. See also id. at 257-8; Griswotd, Cases on Federal Tasation 286 (1946); Note, The Use of Charitable Foundations for Avoidance of Tares, 34 VA. L. REv. 182, 188-9 (1948).

92. The legislative and administrative provisions set out in note 90 supra are precise 


\section{Abuse and Manipulation: The Textron Story}

By the exercise of effective informal control, founders often use foundation $\operatorname{tax}$ benefits and assets to further their own business purposes. The activities of Royal Little, president of Textron, Inc., from 1944 to 1948, illustrate the potentialities of this kind of manipulation. ${ }^{93}$ Involved in these activities were the following charitable trusts controlled by Textron through Little: the Rhode Island Charities Trust and the MIT Trust, formed by Little in 1937 ; ${ }^{94}$ the Rayon Foundation Trust, formed in 1944 at Little's suggestion. ${ }^{06}$

In 1944, Textron needed money to buy textile mills for its post-war expansion program..$^{96}$ The Lonsdale Company, an old New England firm, suited Textron's purposes: it had mills which Textron could use, and its stock was selling at a price far below the potential value of its asscts. If Textron had had funds, and after buying control could have successfully liquidated Lonsdale's excess working capital, it would have made enough immediate profit to pay for the Lonsdale mills. ${ }^{97}$ But Textron, with its credit already strained to the breaking point, could not raise funds to buy the Lonsdale Company stock. ${ }^{98}$ Moreover, Textron did not itself wish to risk the Lonsdale purchase, even if funds were available. It could not bear a loss, and it could ill afford to pay taxes on profits from the speculation, since all profits would be needed to buy the Lonsdale mills.99

Little, as trustee for the Rhode Island Charities Trust, therefore purchased almost all of Lonsdale's outstanding stock for $\$ 6,961,915 .{ }^{100}$ The

and delineated. Retention of a type of control not enumerated in those provisions will therefore bring about no tax penalties.

93. These activities received wide public attention. They were investigated by a subcommittee of the Senate Committee on Interstate and Foreign Commerce from September 22 to December 8, 1948, Hearings before Subcommittec of Conmiltec on Interstate and Foreign Commerce, U.S. Senate, 80th Cong., 2d Sess. (1948), and were putslicized by that committee in a report submitted on March 9, 1949, SEN. REP. No. 101, 81st Cong., 1st Sess. (1949), and in Press Release of Senator Charles W. Tobey, March 25, 1949. Little's activities received further publicity in the press. Sce, c.g., Fiester, Taxes, Dynasties, and Charity, 168 Nation 414 (1949) ; Hepner, Nashita Story, Harper's, Feb., 1949, p. 74; Fortune, May, 1947, p. 133; Id., Aug., 1947, p. 108; Busineys Week, Mar. 5, 1949, p. 82.

94. SEN. Rep. No. 101, supra note 93, at 8, 9; Hearings, supra note 93, at 201-2 (testimony of Royal Little).

95. Sen. Rep. No. 101, supra note 93 , at 8.

96. SEN. REP. No. 101, stura note 93, at 17; Hearings, supra note 93, at 215 (testimony of Royal Little); Fortune, May, 1947, p. 133 at 134.

97. See Sen. Rep. No. 101, supra note 93, at 17; Fortune, May, 1949, p. 133 at 135.

98. SEN. REP. No. 101, supra note 93, at 17; Fortune, May, 1947, p. 133 at 135-6.

99. See SEN. Rep. No. 101, supra note 93, at 22; HIearings, supra note 93, at 302-3 (testimony of Royal Little), 345 (statement of Sen. Tobey, subcommittee chairman).

100. Hearings, supra note 93, at 279 (testimony of Benjamin R. Sturges, trustee of R. I. Charities Trust), 882 (R. I. Charities Trust income tax return for 1945, Sched. E, Ex. II). See also SEN. REP. No. 101, supra note 93, at 17; Hearings, stpra note 93, at 77 (document submitted by Emil Rieve, gen. pres., TWUA (CIO)). 
trust borrowed funds to make the purchase, ${ }^{102}$ and conversion of Lonsdale's assets into liquid capital for distribution to the trust was necessary to enable the trust to repay this debt. Little, as new controlling stockholder of Lonsdale, therefore had Lonsdale sell two of its mills to the Rayon Foundation for approximately $\$ 1,200,000 .{ }^{102}$ Out of the proceeds of this sale, and out of Lonsdale's working capital and profits, Little had Lonsdale declare a $\$ 4,529,790$ dividend on December 15, 1944. ${ }^{103}$ Almost all of this dividend went to the Rhode Island Charities Trust; and a sizable portion of the dividend represented profits on sales of Lonsdale's current and fixed assets. ${ }^{106}$ Additional dividends during 1945 increased the trust's return on its Lonsdale investment to $\$ 5,820,890.105$ Finally, on October 31,1945 , the trust sold its Lonsdale stock to Textron for $\$ 1,654,310,{ }^{103}$ thereby accomplishing Little's original purpose of assimilating the Lonsdale Company into Textron's corporate structure. And the price was extremely low: Lonsdale had an earning capacity of almost $\$ 2,000,000$ a year at the time of the sale. ${ }^{16 \pi}$ Nonetheless, the sale increased the trust's total return on its investment to $\$ 7,475,200,{ }^{108}$ for a net profit of $\$ 513,285$ on the Lonsdale transaction. ${ }^{103}$ This profit was not taxed, ${ }^{110}$ and it would have been many times greater had the trust sold the stock to Textron at its true value.

While these stock transactions were taking place, the mills which Lonsdale had sold in 1944 to the Rayon Foundation were leased back to Lonsdale at a high rental. ${ }^{111}$ The purpose of the original sale was to convert Lonsdale's assets into liquid capital for distribution to the Rhode Island Charities

101. SEN. Rep. No. 101, supra note 93, at 17; Hearings, supra note 93, at 282 (testimony of Godfrey B. Simonds, trustee of R. I. Charities Trust), 943 (account statement of R. I. Charities Trust, Dec 4, 1944) ; Fortune, May, 1947, p. 133 at 136.

102. Hearings, supra note 93 , at 504 (testimony of Bayard Eving, trustee, Rayon Foundation); SEN. ReP. No. 101, supra note 93, at 17; Hcarings, supra note 93, at 77 (document submitted by Emil Rieve, gen. pres., TWUA (CIO)), 907-s (account statement, Rayon Foundation Trust, Dec. 27, 1944, Jan. 20, 1945).

103. Hearings, supra note 93 , at 882 (R. I. Charities Trust, income tax return for 1945, Sched. E, Ex. II), 281 (testimony of Benjamin R. Sturges, trustee, R. I. Charities Trust); SEN. ReP. No. 101, supra note 93, at 17.

104. See Hearings, supra note 93 , at $\mathbf{8 8 3}$ (R. I. Charities Trust, income tax return, 1945, Sched. E, Ex.II).

105. Hearings, supra note 93 , at 882 (R. I. Charities Trust, income tax return for 1945, Sched. E, Ex. II), 281 (testimony of Benjamin R. Sturges, trustee, R. I. Charities Trust).

106. Hearings, supra note 93, at $\$ 82$ (R. I. Charities Trust, income tax return for 1945, Sched. E, Ex. II) ; SEN. REP. No. 101, supra note 93, at 17.

107. In 1946, Lonsdale earned $\$ 1,900,000$, and in 1947, $\$ 1,500,000$. SEN. REP. No. 101, supra note 93, at 18; see also Fortune, May, 1947, p. 133 at 136.

108. Hearings, supra note 93, at 882 (R. I. Charities Trust, income tax return for 1945, Sched. E, Ex. II).

109. Ibid.

110. See note 123 infra.

111. SEN. REP. No. 101, supra note 93, at 17; Hcarings, supra note 93, at 538-9 (testimony of Bayard Ewing, trustee, Rayon Foundation). 
Trust. The lease-back was necessary to enable Lonsdale to continue operating the mills. And the high rental enabled Little to transfer liquid capital from Lonsdale to the Rayon Foundation at a substantial tax-saving: the rents were not taxed to the foundation ${ }^{112}$ and, at the same time, were deductible by Lonsdale from its gross income as expenses. ${ }^{113}$ In less than two years, the Rayon Foundation received more than $\$ 800,000$ in rent from Lonsdale. ${ }^{114}$ And this money was still available to Textron for investment purposes, since Textron, through Little, controlled the Rayon Foundation's investment policies. ${ }^{115}$

Finally on October 1, 1946, a year after Textron had bought the Lonsdale stock from the Rhode Island Charities Trust, Little decided to cut the rental payments on the Lonsdale mills. He therefore had the Rayon Foun. dation sell the mills to the Sixty Trust, a non-charitable trust for the benefit of Textron executives, for only $\$ 865,000.116$ The Sixty Trust then leased the mills to Textron for a flat rental of only $\$ 102,000$ a year. ${ }^{117}$ Thus Textron

112. See note 123 infra.

113. The sale and lease-back device is used widely by large businesses to effect taxsavings in corporate financing. The following is one of many patterns by which such tax-savings can be accomplished:

Instead of floating long term loans, corporations in need of capital now sell their land to universities or other charities. The land is then leased under a lease which is either perpetual at the corporation's option or gives the corporation the right to repurchase at a nominal price. The "rental," after a number of years, will repay the charity its principal and provide the charity with a desirable return on its investment. Meanwhile, the corporation deducts the total "rental" payments from its annual gross income for income tax purposes, whereas, if it merely borrows the money and repays it over an equal number of years at the same rate of return, it can deduct only the interest payments from its annual gross income. The same tax result could be obtained through orthodox financing if land could be retained and depreciated by the corporation for income tax purposes. But since land is not depreciable property, U.S. Treas. Reg. 111, 29.23 (1)-2 (1943), the sale and lease-back of land is the most favorable tax devicc available. See, generally, Cary, Corporate Financing Through the Sale and Lcasc-Back of Property: Business, Tax and Policy Considerations, 62 HARv. L. Rev. 1 (1948).

Charities are usually the collaborators with corporations in the use of the sale and lease-back device. Private investors would balk at a perpetual lease-back to the corporation or an agreement giving the corporation the right to repurchase the land at a nominal price. But charities are interested primarily in a steady and desirable return on their capital rather than investment in real estate for profit purposes. In the Textron type situation, however, the tax advantage in using charities controlled by their founder is greater. High "rentals" can be paid, exceeding the charity's principal investment plus a fair return, see notes 111 stipra and 114 infra; tax exemptions can be claimed by tho corporation for these "rentals"; and the money thus paid to the charities remains available to the corporation for further investment purposes. See note 129 infra.

114. SEN. REP. No. 101, supra note 93, at 19.

115. See SEN. ReP. No. 101, supra note 93, at 22; Hearings, supra note 93, at 414 (testimony of Bayard Ewing, trustee, Rayon Foundation).

116. SEN. REP. No. 101, supra note 93, at 19.

117. Ibid. The change of lessor from the Rayon Foundation to the Sixty Trust was made probably under the assumption that an outright sale of the mills by the foundation 
retained continuous use of the Lonsdale mills at prices controlled by Textron, through Little, at all times.

The trusts, meanwhile, gained on the transactions: the Rhode Island Charities Trust received large dividends from Lonsdale out of operating profits and gains from sales of assets; and the Rayon Foundation received high rentals on its lease back to Lonsdale of the mills which it had purchased. Through transactions of this kind, the three principal trusts accumulated all of their assets. By October, 1948 the Rayon Foundation had accumulated approximately $\$ 750,000 ; 118$ the Rhode Island Charities Trust, $\$ 4,500,000 ;{ }^{110}$ and the MIT Trust, $\$ 1,000,000.120$

From 1944 through 1947, these trusts all claimed deductions of their entire gross incomes under Section 162(a) of the Internal Revenue Code; ${ }^{122}$ and though the Commissioner of Internal Revenue has questioned the propriety of those deductions, ${ }^{122}$ the trusts have never paid any income taxes. ${ }^{123}$ Yet they have spent almost nothing on their beneficiaries. ${ }^{124}$ By October, 1948 the Rhode Island Charities Trust had contributed $\$ 85,000$ to the Providence Community Chest; ${ }^{125}$ the Rayon Foundation had contributed $\$ 75,000$ to the Rhode Island School of Design; ${ }^{15 s}$ and the MIT

would be easier to explain than a drastic reduction in the rentals. See SEr. REp. No. 101, supra note 93, at 18-19. And the change in lessee from Lonsdale to Textron was probably also designed to remove suspicion from the transaction.

118. SEN. REp. No. 101, supra note 93 , at 8 .

119. Ibid.

120. Id. at 9.

121. See, for example, the tax returns of the Rhode Island Charities Trust and the Rayon Foundation Trust for these years. Hearings, supra note 93, at 822-52, 870-83.

122. See, for example, the letter from George J. Schoeneman, Commissioner of Internal Revenue, written on September 5, 1947, informing Bayard Ewing, trustee of the Rayon Foundation, that the foundation was not entitled to tax exemption under Section 101 (6) since it was not "organized and operated exclusively" for charitable purposes. In concluding, the letter stated, "Furthermore, there is no other provision of law under which the trust may be held to be exempt." Hearings, supra note 93, at 506-7. Similar letters were sent to J. Howard MicGrath, one of the trustees of the Rhode Island Charities Trust, on September 8, 1947, id. at 577-8, and to Andrew N. Winslow, Jr., trustee of the MIT Trust, on September 5, 1947, id. at 594. See also SEx. REP. No. 101, rogra note 93 at $24-6$.

123. Sen. Rep. No. 101 , supra note 93 , at $8,9$.

124. Since the trusts argue that their funds were "permanently set aside" for charitable purposes, see Hearings, supra note 93, at 712-33 (testimony of Claude $\mathrm{AC}$. Branch, attorney for the Rayon Foundation and MIIT trusts), such failure to make contributions may not be sufficient in court to nullify the deductions claimed under Section 162(a). See note 89 supra. But trust income earned after 1947 can still be taxed to the founders under Treasury Regulation 111, $\$ 29.22$ (a) -2 (1947), since the founders retained the right to borrow from the trusts without security. See notes 132 infra and 90 stipro. And there is sufficient judicial precedent to enable the taxing of trust income earned before 1947. E.g., Helvering v. Clifford, 309 U.S. 331 (1940).

125. SEN. REP. No. 101, supra note 93 , at 8 .

126. Id. at 9 . 
Trust had contributed nothing to the Massachusetts Institute of Technology. ${ }^{127}$

The trusts could not make regular contributions because their funds were used primarily to finance Textron's further expansion in 1946. That year Textron organized Textron Southern, Inc. to purchase the Gossett mills in North and South Carolina for $\$ 12,000,000 ;{ }^{128}$ and the three trusts bought three-fourths of a $\$ 4,000,000$ class A stock issue of Textron Southern. ${ }^{129}$ The stock bore a $10 \%$ dividend rate and a call price double the issue price. $^{130}$ Yet, in 1947 and 1948 , the trusts exchanged most of their class A stock for Textron stocks and bonds worth less than the call price and paying dividends of $5 \%$ and interest of $41 / 2 \%$ respectively. ${ }^{131}$ Thus the trusts were willing suppliers of Textron's risk capital, and were equally willing to take potential losses on their Textron investments for the benefit of Textron.

Although the trustees were absolved in their trust indentures of all pecuniary liability for their actions, ${ }^{132}$ equity might have compelled them to contribute more than they did to their beneficiaries. ${ }^{133}$ And in spite of broad powers granted to the trustees in the trust indentures, ${ }^{134}$ equity might well have found abuse of discretion, sufficient to warrant injunctions, in the sale by the Rhode Island Charities Trust of its Lonsdale stock to Textron; the sale by the Rayon Foundation of its Lonsdale mills to the Sixty Trust; and the exchanges of Textron Southern class A stock by all three trusts for less desirable Textron stocks and bonds. ${ }^{136}$

But none of the trustees' actions were ever challenged in court. This is typical of the widespread nonenforcement of the terms of charitable foundations throughout the country. ${ }^{136}$ The small foundation, by facilitating the

127. SEN. REP. No. 101, sulpra note 93, at 9 .

128. Fortune, May, 1947, p. 133 at 152; see Hearings, supra note 93, at 218-19 (statement by Royal Little).

129. The Rayon Foundation and the MIT Trust each purchased 50,000 shares for $\$ 500,000$, and the Rhode Island Charities Trust purchased 200,000 shares out of a 400,000 share issue with a par value of $\$ 4,000,000$. SEN. REP. No. 101, sutpra note 93, at 13. See also Hearings, supra note 93, at 906 (account statement, Rhode Island Charities Trust, May 1, 1946), 910 (account statement, Rayon Foundation, May 1, 1946), and 917 (account statement, MIT Trust, May 1, 1946).

130. SEN. REP. No. 101, supra note 93, at 13; Fortune, May, 1947, p. 133 at 155.

131. SEN. REP. No. 101, supra note 93, at 13-16.

132. The texts of the trust indentures are set out in Hearings, stipra note 93, at 318-22 (Rayon Foundation indenture), 508-12 (MIT Trust), and 512-22 (Rlode Island Charities Trust). The indentures relieved the trustees from liability for losses resulting from investment in non-listed and unproductive securities; purchase of securities on margin; short sales of securities; promoting the organization and expansion of business enterprises; underwriting securities; and engaging in "speculative" or "venturesome" transactions. SEN. REP. No. 101, supra note 93, at 11-12. The trustces were also empowered to borrow from their trusts without security. E.g., Hearings, supra note 93, at 319 (Rayon Foundation indenture, 5(f). See note 124 supra.

133. See note 50 supra.

134. See note 132 supra.

135. See note 51 supra.

136. See notes 53-8 supra. 
rapid accumulation of tax-free "charitable" funds, has become a favorite device for tax avoidance, for retention of control over those funds, and for manipulation of the funds for private purposes. ${ }^{157}$ And while these developments preclude faithful performance by trustees or directors of their charitable duties, and have led in recent years to growing abuses by such fiduciaries, ${ }^{138}$ little effort has been made to improve the enforcement of provisions establishing charitable foundations. ${ }^{150}$

But the Textron story reveals a need for more than enforcement of existing controls. Certain of the more obviously disadvantageous transfers from the trusts to Textron violated existing rules. But no present law prevented Textron from using its "charitable" trusts to help finance its own expansion program. ${ }^{140}$ This was not the purpose for which charitable institutions were granted a preferred tax status.

\section{Toward a Concentration of Wealth and Power}

While the Textron trusts, which are not perpetuities, ${ }^{162}$ were designed for

137. "But many of the newer funds do not recognize even a minimum of social responsibility. Two or three hundred of the so-called foundations, including some of the biggest, are simply family trusts: receptacles into which men put funds which thereupon become free of taxes. Their boards of trustees are often simply the founder, one or two members of his family, and his attorney. . . But there is a strong suspicion that in given instances the 'trustees' have used these funds to bolster up a family business. The founder continues, in fact if not in law, to control the funds of many of these trusts and can invest them in any way that suits his whim or his business interest." Embree, Timid Billions: Are the Foundations Doing Thcir Job?, Harper's, MIarch, 1949, p. 26 at 33. See also Harrison and ANDREws 74; Note, The Use of Charilable Foundations for Avoidance of Taxation, 34 VA. L. Rev. 182, 188-9; Fortune, Aug., 1947, p. 108 at 109, col. 2.

138. Abuses in addition to those manifested in the Textron story are: dormancy of foundations through failure to apply the doctrine of cy pres, see notes $\mathbf{5 2}$ and 58 supro; Fortune, Aug., 1947, p. 108 at 143; payment of excessive fees to trustees or directors (this was present to a minor extent in the Textron story, see SEN. REP. No. 101, stipra note 93, at 8) ; Bushnell, Report and Recommendations for Legislation, MIass. L. Q., MIay, 1945 , pp. 22, 30, 32; inefficient foundation administration, id. at 31 ; reversion of foundation property to donors because of non-compliance with conditions of the grant; and foundation inactivity because of failure to appoint trustees. CIO AsD TWUA, STATE:SENiT Before R.I. Spec. Consms. on Charttable Trusts 5-12 (1949); Note, 47 CoL L. Rep. 659,662 (1947).

139. Only New Hampshire has supplemented the attorney-general's cnforcement power, see notes 54-6 supra, with legislation providing for maintenance by the attorneygeneral of a register of charitable trusts. N.H. REv. Laws c. $24 \$ \S 13-a$ to $13-n$, cited

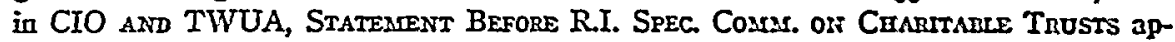
pendix, Ex. IV (1949). The legislation is inadequate, however, since it does not apply to charitable corporations, or inter vivos trusts during the lives of their settlors. Id., \$13-b. Legislation establishing a Division of Public Charities, which was to be applieable to all foundations, was proposed in Massachusetts in 1945 by Attorney-General Bushnell but was not adopted. CIO and TWUA, Stateasent Before R.I. Spec Couss. os: CranrTABLE TRUSTS appendix, Ex. V (1949).

140. SEN. Rep. No. 101, stipra note 93 , at 8 .

141. The Rayon Foundation will terminate 20 years after the deaths of its settlor, 
use only as short-term business weapons, foundations have been employed by their creators to serve long-term economic purposes as well. One such purpose is the continued growth and perpetual preservation of an industrial empire. The Duke Endowment, for example, established in 1924 by James B. Duke, owns more than half the outstanding stock of the Duke Power Company and receives almost all of its income from that source. ${ }^{142}$ The foundation distributes most of its income among universities, colleges, hospitals and churches in the Carolinas. ${ }^{143}$ These groups have occasionally demonstrated their gratitude by vocal support of the Duke power monopoly. ${ }^{144}$ Moreover, the foundation is forever available as a source of capital for the power company. It may not sell any of its Duke Power securities without the unanimous consent of its trustees; ${ }^{145}$ and, since the Duke family. has continuing representation on the board of trustees, ${ }^{146}$ such a unanimous vote is improbable. Furthermore, future foundation investments may be made only in Duke Power securities or domestic government bonds. ${ }^{147}$

Edward Winsor, and another, when all of its property will vest in the Rhode Island School of Design. Hearings, supra note 93, at 319 (Rayon Foundation indenture). The MIT Trust will terminate 20 years after the death of Royal Little when all of its property will vest in the Massachusetts Institute of Technology. Id. at 511 (MIT Trust indenture). And the assets of the Rhode Island Charities Foundation will go to the Rhode Island Foundation after Royal Little's death. Id. at 520 (R.I. Charities Trust indenture).

142. See Tunks $148-50$.

143. See Tunks $149-50$.

144. During the New Deal, for example, a Public Works Administration loan to Greenwood County, South Carolina for a power plant was opposed successfully on the ground that the benefactions of the Duke Foundation would be reduced by construction of a competing power plant. Flexner, Private Fortunes and the Public Future, $156 \mathrm{ATt}$. Montmly 215, 221 (1935). See also Note, The Use of Charitable Foundations for Avoidance of Taxes, 34 VA. L. Rev. 182, 192 (1948); Graves, Benevolent Waler Powver, World's Work, March, 1931, p. 40.

145. TUNKs 149.

146. Ibid.

147. Ibid.

The Duke Endowment presents an outstanding example of private pressure at work. Charles W. Seeman, an ex-Director of the Press of Duke University has made the following charges:

(1) A trustee of the Duke Endowment who was also president of the American Cyanamid Company, in which a trust allied with the Endowment, the Angier B. Duke Memorial, held stock, suppressed a Duke publication as having been issued by "mistake" which failed adequately to credit the Cyanamid product for beetle control.

(2) The results of tobacco research at Duke University, supported largely by the Duke Endowment, go to Liggett and Meyers, in which the Endowment as well as the Doris Duke Trust (the Duke family's private trust), holds stock.

(3) The results of serum development at Duke University go to Lederie Laboratories, a wholly owned subsidiary of American Cyanamid.

(4) The Duke Law School periodical, Law and Contemrorary Pronlems, was subjected to censorship for having commented too favorably on New Deal legislation.

(5) The Endowment forced the resignation of the law school dean, Justin W. Miller. Seeman, Duke But Not Doris, 88 NEw Republic 220 (1936), ; Sceman, In Re- 
The Ford family has provided the most striking modern example of how private individuals may use a charitable foundation as an instrument for the perpetual concentration of economic power. Payment of estate and gift taxes on transfers by the late Henry and Edsel Ford to Henry II would have necessitated sale of a substantial portion of the Ford stock and a consequent reduction of the Ford family's holding in the company. ${ }^{143}$ Both individuals avoided these taxes by donating almost all their stock in the Ford Motor Company to the Ford Foundation. ${ }^{140}$ The foundation, established as a perpetuity in 1936 for "scientific, educational, and charitable purposes," 150 owns Ford non-voting stock valued, as of December 31, 1947, at $\$ 204,855,97515$ Lalmost $90 \%$ of the total equity in the Ford Motor Company. ${ }^{152}$ Henry Ford II controls the foundation, ${ }^{153}$ and foundation contributions to charity during 1947 were under $\$ 1,000,000$-less than $.05 \%$ of total foundation assets. ${ }^{154}$ The institution has served primarily as a

buttal, 89 NEW Republic 48 (1936). Some of these charges were denied by Professor David F. Cavers, editor of Law and Contesrporary Proslesss, and Messrs. Fuller and Maggs of the Duke Law School faculty. Cayers, Fuller and Mfagss, The Duke University Law School In Rebuttal, 88 New Repubuc 311 (1936); Cavers, More About Duke, 89 New RepuburC 114 (1936).

Another example is presented by the Mrilbank Memorial Fund. For a while the Fund financed, in part, the researches of a Committee on the Costs of Mredical Care. The Fund, at that time, was experimenting in the direction of group medicine. The American Medical Association came into sharp contact with the Committec. Albert Milbanl: was president of the Fund and related to the founder, Elizabeth Milibank Anderson; he was, also interested in the Borden Company. And when the A.M.A. threatened to boycott the Borden Company, the Fund withdrew its support of the group medicine researches conducted by the Committee on the Costs of Group Mfedical Care. Coon; MONEY TO BURN 236-40 (1938).

148. The elder Fords did not have enough liquid assets to provide for payment of giff or estate taxes on transfers of their Ford stock See Business Weet; Nov. 13, 1948 , p. 24.

149. Newsweek, May 5, 1947, p. 70; N.Y. Times, April 19, 1947, p. 1, col. 4; id. at p. 21 , col. 2.

150. Fortune, Aug., 1947, p. 108, col. 2; N.Y. Times, April 20, 1947, §4, p. 8, col. 2.

151. Rich aNd DeARDORfF 58.

152. Of a total Ford Motor Company equity of 172,645 shares of class $B$, voting stock and 3,280,255 shares of class $A$, non-voting stock, the foundation owns 3,032,949 shares of class A stock, 1,804,140 of which it received from Henry Ford I, and 1,278,809 from Edsel Ford. Newsweek, May 5, 1947, p. 70 at 71.

153. See Rich and DeardorfF 58; N.Y. Times, April 22, 1947, p. 29, col. 8.

154. The foundation contributed $\$ 92,185.67$ to its beneficiaries during 1947. Rrca AND DEARDORFF 58. The dividends received by the foundation on its Ford arotor Co. stock have not been disclosed by the foundation or the corporation. But the annual report for 1947 filed by the corporation with the Mrassachusetts State Tax Commission showed an increase in surplus of $\$ 48,857,004$ on December 31,1947 over the comparable 1946 figure. Business Week, Sept. 25, 1948, p. 99. This figure, which represents the annual increase in surplus after dividend declarations, indicates that if the foundation, which owns almost $90 \%$ of the corporation's Class A stock, see notes 151 and 152 supro, did not receivè à dividend for 1947 substantially in excess of $\$ 1,000,000$, it should have. And 
medium for transferring control and preserving an accumulation of wealth against tax erosion.

While preservation or growth of dynastic control over finance or industry seldom appears so clearly as the founder's primary motivation, ${ }^{160}$ such accomplishments are a common result. Surplus wealth is donated, tax-free, to a foundation; such wealth is often embodied in securities of an enterprise which the donor controls; through the foundation, the donor continues to control the enterprise; ${ }^{156}$ and since most foundations are perpetual, ${ }^{167}$ control remains in the founder's family indefinitely.

An analysis of the stock holdings of the 200 largest non-financial corporations in the United States holding about $25 \%$ of the assets of all corporntions as of 1937 , revealed the following:

In 64 of the 200 corporations, foundations were among the 20 largest holders of one or more issues of voting stock. ${ }^{163}$ About 40 of the corporations were controlled by small family or business groups; ${ }^{169}$ and perpetual foundations played a complementary role in 11 of these instances. 100 Two family

only the influence of Henry II, who also controls the foundation, sce note 153 supra, could have prevented the declaration of such a dividend.

155. See pp. 497-500 and notes 142-54 supra. After establishing the Duke Endowment, James B. Duke is reported to have said that he "had 'em fixed." Seeman, Duke But Not Doris, 88 New Republic 220 (1936). See also Tunks 148, 153.

156. See note 91 supra.

157. See notes 66 and 67 supra.

158. See THe Distribution of Ownership in the 200 Largest Non-Financiat. Corporatrons Appendix X (TNEC Monograph 29, 1940); TUNKs 116.

159. See The Distribution of Ownersuip in the 200 Largest Non-Financtat. CoRPoratrons 105-9 (TNEC Monograph 29, 1940) ; Tunks 129.

160. Four of the corporations were controlled by small groups through majority ownership of controlling voting stock in the following manner:

\begin{tabular}{|c|c|c|c|}
\hline $\begin{array}{l}\text { Corporation } \\
\text { tulf Oil Corp. } \\
\text { H. Kress \& Co. } \\
\text { uke Power Co. } \\
\text { inderson-Clayton }\end{array}$ & $\begin{array}{l}\text { Family in } \\
\text { Control } \\
\text { Mellon } \\
\text { Kress } \\
\text { Duke } \\
\text { Anderson and } \\
\text { Clayton }\end{array}$ & $\begin{array}{c}\text { Percentage Ozuned } \\
\text { by Foundation } \\
5 \% \\
6 \\
38 \\
47\end{array}$ & $\begin{array}{c}\text { trolled by Fannily } \\
\text { dincluding Fount- } \\
\text { dation Holdings } \\
69 \% \\
85 \\
82 \\
94\end{array}$ \\
\hline
\end{tabular}

Seven of the corporations were controlled through ownership of a substantial minority of controlling voting stock in the following manner:

Corporation

S.S. Kresge Co.

Ohio Oil Co.

Pullman Inc.

Sears, Roebuck \& Co.

Standard Oil Co. of California

Standard Oil Co. of Indiana

Standard Oil Co. of New Jersey
Percentage Controlled by Family,
Family in

Control

Rockefeller

Melion

Rosenwald

Rockefeller

Rockefeller
Percentage Otuned Inteluding Foun: by Foundation dation Holdings $22 \% \quad 44 \%$ 9 (3 founda- 18 210 $.5 \quad 12.5$

$4.5 \quad 11.4$

The Distrdiution of Ownership in the 200 Largest Non-Financial Corporations 105-9, 122-9, 131 Appendix X. (TNEC Monograph 29, 1940); see also Tusrs 129-31. 
groups are outstanding: the Rockefeller group, controlling an estimated 3 per cent of all non-financial corporations, and $6 / 2$ per cent of the 200 leading non-financial corporations, had one-third of its equity owned by various Rockefeller foundations; ${ }^{161}$ and the Mellon group, controlling an estimated 1 per cent of all non-financial corporations, and 21/2 per cent of the 200 leading non-financial corporations, had one-sixth of its equity owned by the A. W. Mellon Educational and Charitable Trust. ${ }^{162}$

While charity may benefit from contributions of all or part of these foundations' income, the benefits are likely to be small compared with those reaped by a founder and his family. ${ }^{103}$ Of course the latter cannot make personal use of the funds. ${ }^{164}$ But they can secure high positions, high salaries and inside opportunities from the companies they continue to control. Moreover, foundations are usually endowed with funds from estate or income which the founder and his descendants do not need for spending purposes anyway. Foundations are thus a painless method for maintaining and augmenting economic power. By not revising the tax-exemption provisions, the federal government has let a small hole in the tax policy against concentrated wealth turn into a gaping breach.

\section{Proposals FOR REFORAI}

Given the purpose behind our tax exemption policy, the only proper function of a charitable foundation is to make the largest possible charitable contributions. The modern privately controlled foundation, whether perpetual or non-perpetual, is not fulfilling this function as well as it should. A short reason for this inadequate performance is that charitable purposes and private business purposes do not always mix.

The principal concern here is not whether it is good or bad, in and of itself, for foundations to operate commercial or industrial enterprises. In these days of low interest rates, business activities may yield much greater annual income than investment in stocks and bonds-as more and more universities are beginning to discover. A public policy which shut off these legitimate efforts to gain more income would be self-defeating. ${ }^{105}$

161. The Distribution of Ownership in the 200 Largest Non-Finazictal CorPORATIONS 126-9 (TNEC Monograph 29, 1940); see TuNzs 131.

162. The Distribution of Ownership in the 200 Largest Non-Fnanctal Co8PORATTONs 122-6 (TNEC Monograph 29, 1940); see Tunks 131.

163. Five hundred and five foundations reported grants of $\$ 52,404,554$ during 1945, HarRison AND ANDREWS $59 ; 186$ reported grants of $\$ 56,779,000$ during 1947 , Ricr Aro DEARDORFF 11; and the latest unofficial estimate of annual foundation contributions, made by the Sloan Foundation, is $\$ 100,000,000$. N.Y. Times, Aug. 17, 1949, p. 21, col. 1 .

164. Once assets or income are spent on private individuals, the foundation, if it is a trust, may not exist perpetually. See notes 61, 63-65 sipra. And no foundation may retain tax privileges once its assets or income are spent on private individuals. Irr. Rer. CoDz $\$ \S 23(0), 23(q), 101(6), 162(a), 812(d), 1004$ (a) (2) (B).

165. The policy would be self-defeating insofar as favored treatment of educational 
The important issue is whether a foundation should be permitted freely to invest in, control or operate a business in which the founder and his heirs have a private interest, or to assist those personages in augmenting their resources. Often such investment will not be the most profitable available to the foundation. But even if it is, the policy against undue concentration of private wealth is circumvented.

This problem is potentially most severe in the case of the perpetual foundation, since perpetuity is more or less essential to large-scale operation of business enterprises or long-term control of economic power. This would be good reason for ending the perpetual foundation entirely unless it can be divorced from private control.

There are additional arguments against the perpetual foundation, apart from the problem of control. It is somewhat paradoxical to justify the institution on the ground that it can engage in activities or investments yielding a higher income for charity. A much higher income to meet existing needs would be achieved by spending principal; yet this by definition a perpetual foundation cannot do. ${ }^{166}$ of course the institution may also be defended as a device providing a sure source of funds for future needs. ${ }^{167}$ But future needs are uncertain indeed, and there is little reason to believe that future generations will be unable to muster resources to solve their own problems. ${ }^{168}$

Whether or not the perpetual foundation is to be eliminated, however, it should be generally agreed (1) that no foundation should become an instru-

and charitable institutions is concerned.

It can be argued that the favoritism should not be pushed to the point that competitive relationships in a particular industry are upset. Assume, for example, that the entire stock of Corporation $A$, a shoe-manufacturing concern, is owned by Corporation $B$, a university. As long as Corporation $B$ is exempted solely from a tax on dividends, and Corporation $A$ has to pay the usual corporate income tax, Corporation $A$ has no competitive advantage, tax-wise, which it can use to cut price and expand its business. But if Corporation $B$ 's immunity is extended through to Corporation $A$, the latter can cut its price and still pay the same dividends-or perhaps greater dividends in the long-run through expansion of its business.

Theoretically the argument is unsound: since the corporate profits tax is deducted "after the fact," it should have no effect on the "best price" for a corporation to chargeif the corporation was maximizing its revenue in the first place, it would not change its price after removal of the tax. But businessmen do not always follow the dictates of economic theory, particularly under changing market conditions, and it is conceivable that elimination of a corporate profits tax would stir a corporation into aggressive expansionary activity.

However, it is quite doubtful that universities would be aggressive butsinessmen. It would be bad public relations, and may actually reduce endowment contributions. For example, a businessman would be loathe to make a donation to a university that was or might become a competitor. See also note 87 supra.

166. See Tunks 237.

167. Harrison ANd ANdrews 69-70; see Tunks 237.

168. See Rosenwald, Principles of Public Giving, 143 ATr. Montrul 599, 606 (1929); Tunks 237. 
ment for private control over wealth or enterprise, and (2) that the Textron type of manipulation should not be permitted to recur.

While the states and Federal Government have done almost nothing along these lines, they have received numerous suggestions. The most recent of these proposals was stimulated by the Textron story. Shortly after a United States Senate subcommittee reported on Textron's activities, ${ }^{10}$ a Special Committee on Charitable Trusts was organized in Rhode Island, home of the Textron foundations, to recommend remedial legislation. The Textile Workers' Union of America (CIO) proposed that the committee recommend amendment of the laws of Rhode Island to require the following:

1. Distribution by all foundations of 85 per cent of their annual income to charitable beneficiaries.

2. Divestment by all foundations of all holdings in excess of 10 per cent of the interest in a particular business enterprise.

3. Limitation of all foundation investments to a list approved by the Commissioner of Banking.

4. Limitation of the lives of all foundations to 25 years. ${ }^{170}$

5. Establishment of a three man Board of Charitable Trusts to enforce these regulations, and creation of a public registry of all foundations to provide the board with all necessary information. ${ }^{171}$

With the exception of the proposal for an active and well-staffed enforcement agency, ${ }^{172}$ these proposals are too arbitrary. A foundation may find it legitimately inadvisable to spend 85 per cent of its income during a given year. Limiting ownership to less than 10 per cent of a business enterprise would prevent a foundation from operating a business even though that business had no connection with the interests of the founder and his successors. A 25 year limit on foundation existence would force liquidation of a going administration organization which, having developed skill in the distribution of charitable benefits, would be a logical recipient of new grants. Finally, restriction of investments to a list approved by the Commissioner of Banking would probably result in ultra-conservative foundation investments to the ultimate detriment of charitable income. ${ }^{173}$

But the principal shortcoming of the union proposal is its confinement to reform on the state level. State limitation of the lives of existing founda-

169. SEN. REP. No. 101, supra note 93.

170. CiO and TWUa, Statearent Before R.I. Spec. Coums, on Craritadie Trusts 3-4, 18-22 (1949).

171. Id. at 2-3, 15-18.

172. Even the commentators most favorable to foundations have consistently urged such reform. See, e.g., Harrison and Andrews 74; Note, The Use of Charilable Foumdations for Avoidance of Taxation, 34 VA. L. REv. 182, 200-1 (1948); Hcarings, sipra note 93, at 208 (testimony of Royal Little).

173. See, for example, the conservative securities approved for trust investments in those states which have promulgated "approved" lists. Statutes cited note 47 stpro. See also 2 Scotr, TRUSts $\$ 227.13$; Tunks 198-9; Legis., 49 HARv. L. REv. 821, 823 (1936). 
tions to 25 years would meet with constitutional objections. As applied to perpetual trusts already in existence, and to corporations organized under special charter, the proposal would probably be unconstitutional under Article II, Section 10 of the Constitution as an impairment of the obligations of the contracts establishing such foundations. ${ }^{174}$ Lives of corporations established under general enabling statutes could probably be limited, on the other hand, since most enabling statutes reserve to the state the power to modify corporate charters. ${ }^{175}$

Moreover, even if there were no constitutional objections, there would be practical difficulties. For state reform to be effective, it must be adopted by all states. Otherwise founders will merely incorporate in states which leave the foundations free. Finally, even if uniform laws were adopted, there might be considerable discrepancies in the efficiency with which they are enforced.

The most recent ${ }^{176}$ official proposal for federal action has ignored almost

174. Trustees of Dartmouth College v. Woodward, 4 Wheat. 518 (U.S. 1819) (state legislature had no power to alter the charter of a charitable corporation which was held to be a contract between the state and the corporation); Cary Library v. Bliss, 151 Mass. 364, 25 N.E. 92 (1890) (Dartmouth College holding extended to charitable trusts). Sec 3 SCOTT, TRUSTS $\$ \S 367.3,399.5$.

175. E.g., Ill. Stat. ANN. c. 32, § $163 a 99$ (Smith-Hurd, Supp. 1948).

176. Two older proposals are significant:

(I) The Walsh Commission report of 1916, prepared by the Commission's director, Basil M. Manly, and joined in by Senator Walsh and Messrs. Lennon, O'Connell and Garretson, recommended the following after extensive hearings at which Louis Brandeis, Samuel Untermeyer, Amos Pinchot, Henry Ford, the Rockefellers, and many others testified:

A. Foundations should be required to obtain a federal charter if their funds exceed $\$ 1,000,000$ and their purposes encompass more than one function. The charter should require:

1. A limit on total funds.

2. A definite statement of powers.

3. A prohibition upon accumulation of funds and upon spending more than $10 \%$ of the principal fund in any one year.

4. Inspection of expenditures and investments by government authority.

5. Annual and complete reports to the government.

6. A prohibition of any activity not enumerated unless

(a) the trustees approve unanimously,

(b) Congress is advised of such proposed action, and

(c) no such action be undertaken until 6 months from such notification.

B. Increased government appropriations for educational and social service. SEN. Doc. No. 415, 64th Cong., 1st Sess., v. 1 pp. 85-6 (1916).

(II) A recommendation by Randolph Paul before the House Ways and Means Committee in 1942 is a simple and expedient one, and might ultimately prove effective if it is ever adopted. Mr. Paul suggested that the estate and gift tax deductions for gifts to charities (see INT. REv. CoDE $\$ \$ 812$ (d) and 1004(a) (2)(B)) be limited to a fixed percentage of the estate in the same manner as income tax deductions for charitable gifts are limited to $15 \%$ of individual gross income, $i d ., \S 23(0)$, and $5 \%$ of corporate gross income, id., $\$ 23(\mathrm{q})$. Hearings before the Committee on Ways and Mcans on Revemic 
all the essential elements of adequate control. In February, 1949, a subcommittee of the Senate Committee on Interstate and Foreign Commerce, after investigation of Textron's operations, recommended the following: "[S]ection 162 of the Internal Revenue Code [should] be amended to provide that no trust shall receive benefits under Section 162(a) . . . unless during the taxable year it has actually paid to its beneficiary 85 per cent of its gross income received in such taxable year." 17

Concededly, this amendment of 162(a) would prevent a recurrence of the Textron story. Not having been qualified by the Bureau of Internal Revenue for exemption under 101(6), , $^{178}$ the Textron trusts claimed, and apparently were allowed, deductions of their entire incomes under 162(a) from 1944 through $1947 . .^{179}$ And since Textron used the trusts to accumulate funds, tax exempt, for its ultimate benefit, a requirement that such trusts either contribute 85 per cent of their income to charity or lose their tax privileges under 162(a) would effectively block identical schemes in the future.

But the subcommittee proposal, in failing to recommend similar amendment of 101(6), would leave unmolested most manipulation of foundation assets for short-term business purposes. Most foundations are incorporated, ${ }^{123}$ and since 162(a) does not apply to corporations, the majority of foundations claim tax exemption under 101(6). And the liberal interpretation already given by courts to that section as applied to foundations actually earning income from business operations ${ }^{181}$ would assure the continued tax-free accumulation of foundation assets.

But even with a similar amendment of $101(6)$, long-term preservation of wealth or economic power through perpetual foundations would remain unhampered. Restriction upon accumulation of income alone is incapable of curtailing such practices, since successful preservation of wealth and economic control depends primarily on preservation of principal rather than accumulation of income. Yet the subcommittee suggested no restriction upon foundation preservation of principal. Nor did it suggest any method of liberating foundations from control by private interests-an alternative way of insuring that foundations remain "charitable." .

\section{New Proposals}

Woefully inadequate as the Senate subcommittee's proposal may have been, the group was quite correct in seeking stricter regulation of foundations

Revision of 1942, 77th Cong., 2d Sess., v. 1 pp. 91-2 (1942). While this proposal does not attack foundation evils directly, it might at least limit foundation assets sufficiently to make them of little long-term use to their founders.

177. SEN. REp. No. 101, supra note 93, at 23-4; S. 1408, S1st Cong, 1st Sess. (1949).

178. See letters to the trusts from the Commissioner of Internal Revenue, cited supro note 122 .

179. See notes 121 and 123 stipra.

180. See note 31 supra.

181. See note 87 supra. 
under the federal taxing power. Some of the loopholes may be narrowed by new Treasury regulations and more active Treasury enforcement under the present Code. ${ }^{182}$ But new tax provisions are necessary for adequate and unambiguous elimination of private gain from charitable foundations.

The following recommendations are offered in the alternative. Recommendation " $\mathrm{A}$ " is the more limited proposal. It assumes that private control and manipulation can be effectively eliminated from all foundations, without ending the perpetual foundation as such:

\section{Recommendation " $A$ "}

"1. In order for a foundation to qualify for income tax exemption under Section 101(6) or income tax deductions under Section 162(a) of the Internal Revenue Code,

(a) no person shall at any time act in the capacity of trustee ${ }^{188}$ if he or any member of his family is a director of, or controls directly or indirectly (1) a business in which the foundation has invested 10 per cent or more of its assets or which the foundation directly or indirectly controls, or (2) a business which deals, except in the ordinary course of trade, with an enterprise in which the foundation has invested 10 per cent or more of its assets or which the foundation directly or indirectly controls; and

(b) no corporation ${ }^{184}$ shall act in the capacity of a trustee of a foundation if such corporation is controlled directly or indirectly (1) by

182. The Treasury might try to define the word "charitable" more preciscly than courts have defined it in the past. A definition precluding founders from benefiting privately from their foundations would be consistent with the purposes of the "charity" sections of the Code. But the courts may hold a restrictive definition to be a substantive change in the Code, or an administrative amendment of an unambiguous statute, and therefore beyond the scope of the Treasury's regulating power. See notes 83,87 and 89 supra. See, e.g., Koshland v. Helvering, 298 U.S. 441 (1936) (receipt by preferred shareholder of a common stock dividend, held income under the Code; and Treasury declared powerless to tax such income as a capital gain under statute clearly providing for taxation only of capital gains).

In view of the Treasury's past lethargy in attacking charitable tax privileges, a regulation redefining "charity" might also be invalidated on the ground of novelty. See pp. 489 and 490 and note 87 supra. See, e.g., Iselin v. United States, 270 U.S. 245 (1926) (taxation of sale by stockholder, at more than "established price," of box tickets acquired as part of investment in opera house company, held invalid, partly because the tax on sales above "established price" was not previously so applied with consistency or uniformity).

Finally, the setting apart of foundations from other institutions would be vulnerable to attack. Such a distinction would be justifiable, since schools, hospitals and churches have thus far remained relatively free of the disruptive pulls of private interest. But the distinction is not made in the Code, and the Treasury might therefore be precluded from making it.

183. "Trustee" means trustee, director or manager.

184. "Corporation" means corporation, partnership, individual proprietorship or any other business association. 
a business in which the foundation has invested 10 per cent or more of its assets or which the foundation directly or indirectly controls; or (2) a person not eligible to act as trustee; nor shall a director of such corporation act in the capacity of trustee.

"2. No estate tax deduction under Section 812(d), gift tax deduction under Section 1004(a)(2)(B) or income tax deduction under Sections 23(o) and 23(q) of the Internal Revenue Code shall be allowed for a contribution to a charitable foundation not meeting the requirements of Section 1; provided that deductions shall be allowed to any person or corporation which would be eligible to act in the capacity of trustee." 185

Recommendation " $\mathrm{B}$ " is proposed as an alternative in case (1) it should be considered desirable to require the expenditure of principal of charitable grants, and (2) it should be deemed unduly optimistic to assume that private control over foundations can be eliminated. ${ }^{185}$ The proposal is designed to sterilize private control rather than to end it:

\section{Recommendation " $B$ "}

"1. No estate tax deduction under Section 812 (d), gift tax deduction under Section 1004(a)(2)(B) or income tax deduction under Sections 23(o) and 23(q) of the Internal Revenue Code shall be allowed for a contribution to a charitable foundation which

(a) does not plan in good faith to expend the principal and income of its original grant and of any subsequent donations within 25 years of the date on which the grant or donation was received; or

(b) does not plan in good faith to so diversify its investments that no more than 10 per cent thereof is lodged in securities or assets of any one business enterprise or group of enterprises controlled directly or indirectly by persons who also control the foundation; provided that a reasonable period, not to exceed 10 years after receipt of the original or later donation, shall be given within which to accomplish any necessary reduction;

(c) nor will any of said tax deductions be allowed for a contribution by a person ${ }^{187}$ to a foundation which he directly or indirectly controls if the foundation's funds are used at any time to further acquire assets or securities of a business enterprise related to that under his direct or indirect control.

185. These provisions are comparable to those in other statutes which scek to regulate "control." See, e.g., Trust Indenture Act of 1939, §310(b), 53 SinT. 1158-61 (1939), 15 U.S.C. $\S 77 \mathrm{jjj}(\mathrm{b})$ (1946); Public Utility Holding Company Act, §2(a), 49 SזsT. 804-810 (1935), 15 U.S.C. \$ 79b(a) (1946); Securities Exchange Act of 1934, § 16(a), 48 STAт. 896 (1934), 15 U.S.C. $\$ 78 p(a)$ (1946).

186. See note 91 supra.

187. "Person" means any individual, corporation or any other business association. 
"2. No foundation will be allowed income tax exemption under Section 101(6) or income tax deductions under Section 162(a) of the Internal Revenue Code, where such foundation

(a) [same as Section 1 (a)]; or

(b) [same as Section 1 (b)]; or

(c) uses its funds at any time during the year to further acquire assets or securities of a business enterprise controlled directly or indirectly by persons who also control the foundation, or to acquire assets or securities of a business enterprise related to that under direct or indirect control of persons who also control the foundation."

Applied only to future founder deductions and foundation immunities, ${ }^{183}$ both of these recommendations would be invulnerable to constitutional attack. No foundation has an inherent right to retention of its tax privileges. Moreover, foundations affected by the proposed legislation would not be forced to give up their privileges. Corporate directors could amend their articles of incorporation, ${ }^{189}$ and trustees could apply to a court of equity for reformation of their trust indentures ${ }^{190}$ to comply with the proposed requirements. The requirements of either recommendation could not be challenged as an impairment of the obligations of contract when applied to existing trusts and corporations: tax privileges existing at the time of formation of a trust or corporation are not included among the "obligations of contract" between the settlor and his trustee, or between the chartered corporation and the government. 191

Adoption of the proposed legislation would place a heavy fact-finding burden on the Bureau of Internal Revenue. To facilitate enforcement, all foundations should be required to make full disclosure to the Treasury of their business interests, charitable and business expenditures, and internal administration. Most of this information, with the notable exception of stock voting policy, is already supplied to the Treasury by organizations

188. Although Congress may tax income retroactively, at least for a period of less than 12 months in the past, e.g., Brushaber v. Union Pacific R.R., 240 U.S. 1 (1915), there are indications that a retroactive income tax for a longer period in the past would be invalidated. See Brushaber v. Union Pacific R.R., supra, at 20; Cohan v. Commissioner, 39 F.2d 540, 545 (2d Cir. 1930). And retroactive application of gift taxes for only a few months in the past has been held unconstitutional. Untermyer v. Anderson, 276 U.S. 440 (1928); Blodgett v. Holden, 275 U.S. 142 (1927).

Effective future application of the requirements might require a longer statute of limitations for the "charity" provisions of the Code. The present period, with some minor exceptions, is three years. INT. REV. CoDE $\$ 275$ (income tax), \$874 (estate tax) and $\$ 1016$ (gift tax). Under a longer period, if a foundation were to violate these provisions after five or ten years of compliance, the Treasury would still be able in appropriate cases to tax the foundation's original grants.

189. See notes 42 and 52 supra. To comply with Recommendation "A," charter amendment is not necessary. Ineligible directors can simply resign.

190. See note 58 supra.

191. E.g., Wisconsin and Michigan Ry. v. Powers, 191 U.S. 379 (1903). 
claiming tax exemptions under Section $101(6)$ in their annual returns. ${ }^{102}$ But trusts claiming deductions under Section $162(a)$ are required to reveal very little. ${ }^{193}$

It should hardly be necessary to add that Congress should appropriate enough money for the Treasury to carry out its enforcement duties.

\section{Conclusion}

The modern philanthropic foundation, originally designed to perform only a public function, has been tailored to serve private purposes as well. In its philanthropic accomplishments, the foundation has often fallen short of its tremendous potential. To prevent further deterioration, it has been proposed that tax exemptions be withdrawn from those foundations which serve two masters. Either of the recommendations advanced would go far toward eliminating private gain from public charity and thereby maximizing the benefits which the public actually derives.

These proposals may be subjected to the criticism that they would "dry up the source of foundation contributions." 194 But such criticism is based on the faulty assumption that practically all foundations are established primarily for private rather than public good. This assumption seems amply refuted by history. ${ }^{195}$

But if indeed most foundations are created primarily for private purposes and would therefore be wiped out by withdrawing the bribes of private economic gain, benevolence need not be put to an end. Should resort to foundations decline, additional tax revenues would accrue to the federal and state governments. This money could then be used to fulfill in practice the beneficent purposes which privately-controlled foundations have often ignored.

192. This information is supplied in Form 990 and Form 1023, 1024 or 1026, pursuant to Section 54(f) of the Internal Revenue Code. See Turrs 282-3, 298-9.

193. These organizations file Form 1041 pursuant to Section 142 of the Internal

Revenue Code. See Tunks 282-3, 298-9.

194. Tunks 311.

195. See notes 16 and 18 supra. 